\title{
Seasonal lead release to drinking water and the effect of aluminum
}

Benjamin F. Trueman, ${ }^{*}, 1$ Aaron Bleasdale-Pollowy, ${ }^{1}$ Javier A. Locsin, ${ }^{1}$ Jessica L. Bennett, ${ }^{1}$ Wendy H. Krkošek, ${ }^{2}$ and Graham A. Gagnon ${ }^{1}$

${ }^{1}$ Centre for Water Resources Studies, Department of Civil \& Resource Engineering, Dalhousie University, 1360 Barrington St., Halifax, Nova Scotia, Canada B3H 4R2

${ }^{2}$ Halifax Water, 450 Cowie Hill Rd., Halifax, Nova Scotia, Canada, PO Box 8388, B3K $5 \mathrm{M} 1$

${ }^{*}$ Corresponding author

E-mail: benjamin.trueman@dal.ca

Tel: 902.494 .6070

Fax: 902.494 .3105

\section{Abstract}

Monitoring lead in drinking water is important for public health, but seasonality in lead concentrations can bias monitoring programs if it is not understood and accounted for. Here, we describe an apparent seasonal pattern in lead release to orthophosphatetreated drinking water, identified through point-of-use sampling at sites in Halifax, Canada, with various sources of lead. Using a generalized additive model, we extracted the seasonally-varying components of time series representing a suite of water quality parameters and we identified aluminum as a correlate of lead. To investigate aluminum's role in lead release, we modeled the effect of variscite $\left(\mathrm{AlPO}_{4} \cdot 2 \mathrm{H}_{2} \mathrm{O}\right)$ precipitation on lead solubility, and we evaluated the effects of aluminum, temperature, and orthophosphate concentration on lead release from new lead coupons. At environmentally relevant aluminum and orthophosphate concentrations, variscite precipitation increased predicted lead solubility by decreasing available orthophosphate. Increasing the aluminum concentration from 20-500 $\mathrm{g} \mathrm{L}^{-1}$ increased lead release from coupons by $41 \%$ and modified the effect of orthophosphate, rendering it less effective. We attributed this to a decrease in the concentration of soluble $(<0.45 \mu \mathrm{m})$ phosphorus 
with increasing aluminum and an accompanying increase in particulate lead and phosphorus $(>0.45 \mu \mathrm{m})$.

Keywords: Variscite, PHREEQC, generalized additive model, orthophosphate, mgcv

\section{Synopsis}

Water treatment with aluminum salts can cause seasonally high aluminum concentrations that interfere with orthophosphate corrosion control.

\section{Graphical abstract}
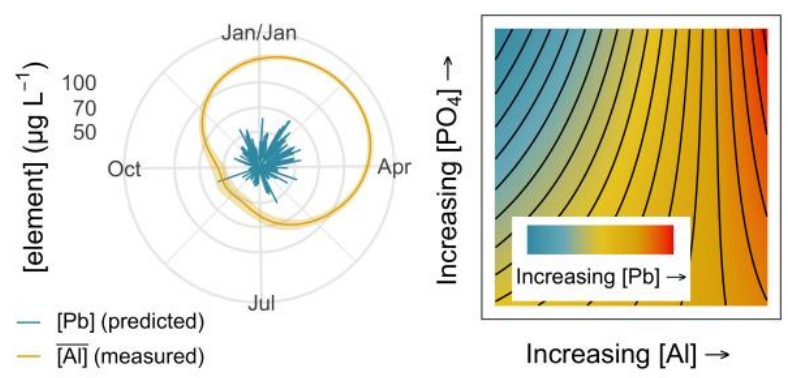

\section{Introduction}

Lead is a contaminant of concern in drinking water due to its well-documented health effects. ${ }^{1,2}$ Many jurisdictions require that it be monitored, but seasonal variation in lead release can bias monitoring programs if it is not understood and accounted for. Temperature-driven seasonal lead release has been described in previous work, ${ }^{3}$ and sampling guidance is often designed to control for temperature effects. ${ }^{4}$

But water quality parameters other than temperature can also contribute to seasonal lead concentrations, and aluminum is an important example. Aluminum concentrations can vary seasonally when water is treated to remove particles and dissolved organic matter by coagulation. This is because the solubility of the aluminum hydroxide $\left(\mathrm{Al}(\mathrm{OH})_{3}\right)$ that precipitates during coagulation with aluminum salts is highly temperature- 
dependent. Below the solubility minimum at $\mathrm{pH} 6-7,{ }^{5}$ solubility decreases with increasing temperature, and above $\mathrm{pH} 6-7$, solubility increases with temperature. ${ }^{6}$ Treatment facilities that coagulate below the $\mathrm{pH}$ of minimum solubility, then, tend to see high residual aluminum in winter, while facilities that coagulate at alkaline $\mathrm{pH}$ may see high aluminum in summer. ${ }^{7}$

This in turn may influence lead release, but the complex environment of a drinking water distribution system —and the possibility of multiple competing mechanisms-make it difficult to predict aluminum's net effect. Aluminum might precipitate at the scale-water interface as a hydroxide or silicate mineral that slows lead diffusion to the bulk water, ${ }^{8-11}$ but this is controversial. ${ }^{12,13}$ It might also precipitate as a phosphate mineral, diminishing the activity of orthophosphate and preventing formation of hydroxypyromorphite $\left(\mathrm{Pb}_{5}\left(\mathrm{PO}_{4}\right)_{3} \mathrm{OH}\right)$ and other low-solubility phases that control lead release. ${ }^{5,11,14-18}$ Aluminum precipitation that results in suspended particles or colloids may generate a mobile sink for lead, facilitating lead transport from source to tap. ${ }^{19-21}$

Here, we consider aluminum and other seasonally-varying water quality parameters as drivers of seasonal lead release. We use a hybrid approach that combines statistical analysis of observational data, a factorial experiment, and a mechanistic model. We identify possible origins of periodic lead release in the distribution system of Halifax, a mid-sized North American city, and we isolate a subset of these-aluminum, orthophosphate, and temperature-for investigation using a lead coupon study and a geochemical solubility model. We find that interactions between orthophosphate and aluminum have an important effect on lead release and that variation in aluminum concentrations may play a key role in observed lead concentrations. In our view, mechanisms involving soluble, colloidal, and particulate lead are all relevant to this phenomenon. 


\section{Materials and methods}

\section{Field sample collection}

\section{Distribution system monitoring}

Distribution system samples were collected by utility staff as part of a routine, long-term monitoring program designed to understand the state of the system and respond to water quality issues. Temperature and pH were measured in the field (Hach PH281 probe), and samples were sent to a third-party accredited laboratory for determination of alkalinity, ${ }^{22}$ total aluminum, ${ }^{23}$ and orthophosphate. ${ }^{24}$

\section{Point-of-use corrosion control monitoring}

The point-of-use corrosion control monitoring dataset represents two distinct monitoring programs, described in Mcllwain ${ }^{25}$ and Trueman et al. ${ }^{26}$ The first comprised samples collected at residential ( $1 \mathrm{~L}$ volume) and non-residential $(0.25 \mathrm{~L}$ volume) sites in the distribution system after a minimum 8 hour stagnation period (Table 1). ${ }^{25}$ Samples were collected over three years (2010-2012), representing two October and two February collection periods. This program was designed to evaluate the utility's corrosion control program and to identify outlets with high lead levels. The 34 residential sites included three and six with full and partial lead service lines, respectively. A further 18 had copper service lines and the remaining 7 had unknown configurations. Outlets used for drinking or cooking were sampled in 48 non-residential buildings. ${ }^{25}$

The second program was designed to evaluate the effect of lead service line replacement on lead levels in tap water. ${ }^{26}$ Volunteers residents collected $1 \mathrm{~L}$ samples as $4 \times 1 \mathrm{~L}$ minimum $6-\mathrm{hr}$. stagnant profiles with the addition of a 5-min. flushed sample after each profile (Table 1). We filtered a subset of these using $0.45 \mu \mathrm{m}$ membrane filters in a syringe-mounted apparatus. To quantify aluminum in the distribution system, we used 5-min. flushed samples only, to minimize the impact of site-specific factors (e.g., premises plumbing). To estimate particulate lead and copper, we used samples collected before replacement, since extreme particulate lead release is typical immediately after replacement. 
All samples were collected in high-density polyethylene (HDPE) bottles, cleaned by immersion in $2 \mathrm{M} \mathrm{HNO}_{3}$ for at least $24 \mathrm{~h}$, and rinsed thoroughly with ultrapure water. Aluminum, lead, copper, and phosphorus were determined by ICP-MS (Thermofisher $X$ series II) according to Standard Method $3125,{ }^{27}$ with reporting limits of $4.0,0.4,0.7$, and $10 \mu \mathrm{g} \mathrm{L}^{-1}$, respectively.

Table 1. Data sources, sample sizes, and figures in which specific datasets appear.

\begin{tabular}{|c|c|c|c|}
\hline Data source & Analytes & $\begin{array}{l}\text { Appears } \\
\text { in Figure }\end{array}$ & Source \\
\hline $\begin{array}{l}\text { Volunteer-collected } 1 \\
\text { L flushed samples }\end{array}$ & $\begin{array}{l}\text { Total Al }(n=849), 0.45 \mu \mathrm{m}- \\
\text { filtered Al }(n=362)\end{array}$ & $2,4 b, 7 c$ & Utility data \\
\hline $\begin{array}{l}\text { Plant/distribution } \\
\text { system monitoring } \\
\text { data }\end{array}$ & $\begin{array}{l}\mathrm{Al}(\mathrm{n}=1217), \mathrm{PO}_{4}(\mathrm{n}=2708) \\
\text { temperature }(\mathrm{n}=1595) \\
\text { alkalinity }(\mathrm{n}=414), \mathrm{pH}(\mathrm{n}= \\
\text { 414), orthophosphate product } \\
\text { dose }(\mathrm{n}=6035)\end{array}$ & $2,7 \mathrm{c}$ & Utility data \\
\hline $\begin{array}{l}\text { Volunteer-collected } 1 \\
\text { L profile samples }\end{array}$ & $\begin{array}{l}\mathrm{Pb}, \mathrm{Cu}(\mathrm{n}=360 \text { per } \\
\text { parameter })\end{array}$ & $\mathrm{S} 11$ & Utility data \\
\hline $\begin{array}{l}\text { Volunteer-collected } 1 \\
\text { L profile samples }\end{array}$ & $\begin{array}{l}\text { Al, Fe, Pb, via SEC-ICP-MS ( } n \\
=16)\end{array}$ & $4 a$ & doi.org/10.5281/zenodo.5139734 \\
\hline $\begin{array}{l}\text { Residential } 1 \mathrm{~L} \text { first- } \\
\text { draw and flushed } \\
\text { samples }\end{array}$ & $\begin{array}{l}\mathrm{Pb}(\mathrm{n}=193), \mathrm{Cu}(\mathrm{n}=193), \mathrm{pH} \\
(\mathrm{n}=125), \text { temperature }(\mathrm{n}= \\
86), \text { turbidity }(\mathrm{n}=192)\end{array}$ & 3 & $\begin{array}{l}\text { Mcllwain et al. }{ }^{25} \text { and } \\
\text { doi.org/10.5281/zenodo.5139734 }\end{array}$ \\
\hline $\begin{array}{l}\text { Non-residential } 0.25 \\
L \text { first-draw and } \\
\text { flushed samples }\end{array}$ & $\begin{array}{l}\mathrm{Pb}(\mathrm{n}=303), \mathrm{Cu}(\mathrm{n}=303), \mathrm{pH} \\
(\mathrm{n}=232), \text { temperature }(\mathrm{n}= \\
148), \text { turbidity }(\mathrm{n}=303)\end{array}$ & 3 & $\begin{array}{l}\text { Mcllwain et al. }{ }^{25} \text { and } \\
\text { doi.org/10.5281/zenodo.5139734 }\end{array}$ \\
\hline Coupon study & $\begin{array}{l}\text { Total } \mathrm{Pb}, \mathrm{Al}, \mathrm{P}(\mathrm{n}=128 \text { per } \\
\text { parameter }) ; 0.45 \mu \mathrm{m} \text {-filtered } \\
\mathrm{Pb}, \mathrm{Al}, \mathrm{P}(\mathrm{n}=32 \mathrm{per} \\
\text { parameter })\end{array}$ & 5 & doi.org/10.5281/zenodo.5139734 \\
\hline
\end{tabular}

\section{Size-exclusion chromatography}

Relative size distributions of lead, aluminum, and iron were determined for a subset of the profile samples described above (see "Point-of-use corrosion control monitoring"), using size-exclusion chromatography with multielement detection (SEC-ICP-MS). The full method is detailed in a previous publication. ${ }^{20}$ Briefly, we separated samples on a stationary phase composed of cross-linked agarose and dextran (Superdex 200, $10 \times$ $300 \mathrm{~mm}, 13 \mu \mathrm{m}$ particle size, GE Healthcare) with $50 \mathrm{mM}$ tris- $\mathrm{HCl}$ ( $\mathrm{pH} 7.3)$ as the mobile phase. The flow rate was $0.5 \mathrm{~mL} \mathrm{~min}^{-1}$ and the injection volume was $212 \mu \mathrm{L}$. We monitored ${ }^{27} \mathrm{Al},{ }^{56} \mathrm{Fe}$, and ${ }^{208} \mathrm{~Pb}$ in the column effluent as a function of time by ICP-MS 
(see Point-of-use corrosion control monitoring above). The retention volume of thyroglobulin (669 kDa, Stoke's radius $8.5 \mathrm{~nm}$ ), indicated in chromatograms as a qualitative point of reference, was monitored as ${ }^{127}$. Chromatograms were summarized as the sum of two skewed or exponentially modified Gaussians using the R package fffprocessr, ${ }^{28}$ as described elsewhere. ${ }^{29} \mathrm{R}$ code to reproduce the analysis is included as Supplementary Text S1, the individual chromatograms are shown in Figure S1, and the data are available at doi.org/10.5281/zenodo.5139734.

\section{Lead coupon study}

We investigated the effect of three factors-aluminum ( 0.02 or $\left.0.5 \mathrm{mg} \mathrm{Al} \mathrm{L}^{-1}\right)$, orthophosphate (0 or $1 \mathrm{mg} \mathrm{PO}_{4} \mathrm{~L}^{-1}$ ), and temperature $\left(4\right.$ or $21^{\circ} \mathrm{C}$ )—on lead release from new lead coupons using a set of batch corrosion cells made with new lead coupons. Using a $2^{3}$ factorial design (Table S1), we evaluated all eight factor combinations (two aluminum concentrations $\times$ two orthophosphate concentrations $\times$ two water temperatures) to generate independent estimates of each factor's effect, along with estimates of the interactions among factors.

\section{Preparation of test water}

Preparation of test water for the coupon study is summarized in Figure 1. We coagulated untreated source water from the water supply plant with $\mathrm{Al}_{2}\left(\mathrm{SO}_{4}\right)_{3} \cdot 18 \mathrm{H}_{2} \mathrm{O}$ (12 $\mathrm{mg} \mathrm{Al} \mathrm{L}^{-1}$ ) in a $20 \mathrm{~L} \mathrm{HDPE} \mathrm{plastic} \mathrm{container.} \mathrm{The} \mathrm{coagulant} \mathrm{dose} \mathrm{was} \mathrm{chosen} \mathrm{to}$ match the dose applied at the treatment plant supplying the distribution system we studied.

Immediately after adding the coagulant, water was mixed at approximately $800 \mathrm{rpm}$ for one minute using a magnetic stirplate (n.b., rpm is nominal and was determined by the stirplate dial setting). Coagulated water was then mixed for 12.5 minutes each at 600 , 500 , and $400 \mathrm{rpm}$. pH was maintained throughout at 6.3 using sodium hydroxide. The flocculated water was allowed to settle overnight, pumped into a separate reservoir, and filtered using a vacuum flask fitted with a $1.5 \mu \mathrm{m}$ glass-fibre filter membrane. 


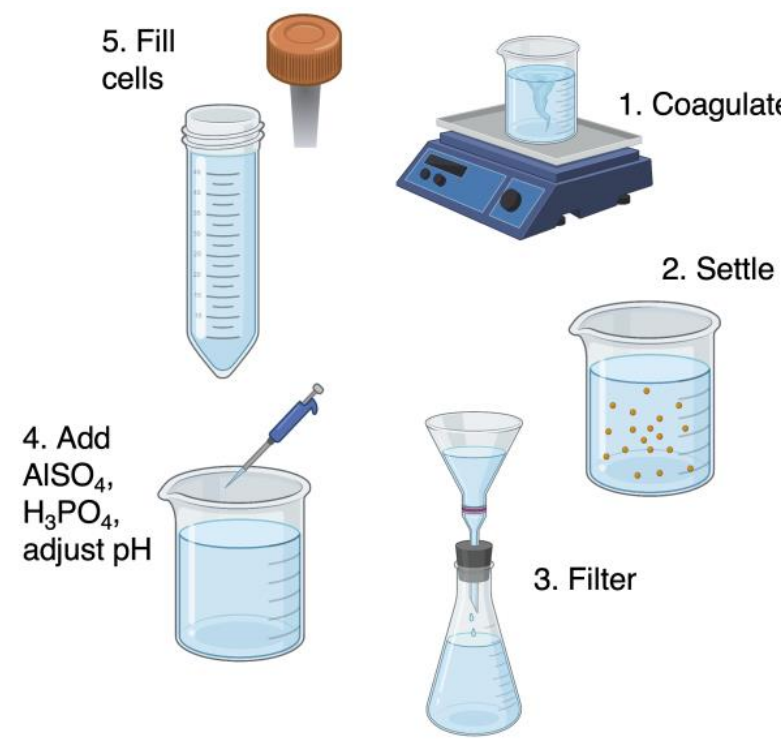

Figure 1. Summary of test water preparation for the coupon study (created at biorender.com). This procedure reduced total organic carbon (TOC) to $1.8 \mathrm{mg} \mathrm{L}^{-1}$ (standard deviation $0.02 \mathrm{mg} \mathrm{L}^{-1}$ ), from an approximate raw water concentration of $3.8 \mathrm{mg} \mathrm{L}^{-1}$ (a summary of untreated water quality is provided in Table S2). TOC samples were collected, headspace-free, in $40 \mathrm{~mL}$ clear glass vials and preserved with concentrated phosphoric acid to $\mathrm{pH}<2$. Vials were washed and then baked at $105^{\circ} \mathrm{C}$ for at least $24 \mathrm{~h}$ before use, and TOC was quantified using a Shimadzu TOC-V CPH analyzer. ${ }^{30}$

Filtrate was dosed as needed with $\mathrm{H}_{3} \mathrm{PO}_{4}, \mathrm{Al}_{2}\left(\mathrm{SO}_{4}\right)_{3} \cdot 18 \mathrm{H}_{2} \mathrm{O}$, and $\mathrm{NaHCO}_{3}\left(5 \mathrm{mg} \mathrm{C} \mathrm{L}^{-1}\right)$ to achieve the experimental conditions listed in Table $\mathrm{S} 1$. The initial $\mathrm{pH}$ for all test waters was adjusted to 7.5 with $\mathrm{HNO}_{3}$ and $\mathrm{NaOH}$. $\mathrm{pH}$ was measured using a combination electrode, and the nominal orthophosphate concentration was verified colorimetrically. ${ }^{24}$

\section{Corrosion cell construction}

Corrosion cells were constructed by fastening new lead coupons to the lids of $50 \mathrm{~mL}$ polypropylene centrifuge tubes with a silicone sealant. Beforehand, coupons (Canada Metal North America, Québec, Canada) were cleaned by immersion for 2 minutes in 1.8 $\mathrm{M} \mathrm{HNO}_{3}$ followed by thorough rinsing with ultrapure water. This step was repeated afterward with $40 \mathrm{mM} \mathrm{HNO}_{3}$. 


\section{Coupon conditioning}

Corrosion cells were refilled with $50 \mathrm{~mL}$ of fresh test water according to the experimental design summarized in Table S1; this volume was chosen to prevent contact with the sealant while minimizing headspace. We completed 42 changes of water before beginning to collect data, and each change was followed by a minimum 24 hour stagnation period. After conditioning, lead in $0.45 \mu \mathrm{m}$ filtrate agreed reasonably well with predicted equilibrium lead solubility, with a mean absolute error of $8 \mathrm{\mu g} \mathrm{L}^{-1}$ at the low level of aluminum, a temperature of $21^{\circ} \mathrm{C}$, and either 0 or $1 \mathrm{mg} \mathrm{PO}_{4} \mathrm{~L}^{-1}$.

\section{Sample collection}

After each 24-hour stagnation period, cells were mixed by inverting five times. Aliquots of $10 \mathrm{~mL}$ were then decanted into polypropylene tubes, acidified to $\mathrm{pH}<2$ with concentrated trace metal grade nitric acid, and held for a minimum of 24 hours before analysis. Separate $10 \mathrm{~mL}$ aliquots were filtered, immediately after collection, using 0.45 $\mu \mathrm{m}$ membrane filters in a syringe-mounted apparatus.

\section{X-ray diffraction}

We identified crystalline phases in coupon corrosion scale using X-ray diffraction (XRD). Coupons were dried and analyzed without removing scale from the surface. We used a Rigaku Ultima IV X-ray diffractometer with a copper $\mathrm{K} \alpha$ radiation source, operated at 35 $\mathrm{kV}$ and $30 \mathrm{~mA}$. Scans were acquired over the range $10-70^{\circ}(2 \theta)$ with a step size of $0.04^{\circ}$ and a scan speed of $0.8^{\circ} \mathrm{min}^{-1}$. The powder diffraction file numbers corresponding to standards referenced in the manuscript are listed in Table S3.

\section{X-ray photoelectron spectroscopy (XPS)}

The elemental composition of corrosion scale was determined by XPS using a Thermo VG Scientific Multilab 2000 instrument. An aluminum X-ray source was used under a high vacuum, and a CLAM4 Hemispherical Analyzer with a multichannel detector was used to detect photoelectrons. Survey scans were acquired at a pass energy of $50 \mathrm{eV}$ with a step size of $1.0 \mathrm{eV}$, and high-resolution scans were acquired at a pass energy of 
$30 \mathrm{eV}$ with a step size of $0.1 \mathrm{eV}$. Binding energy was calibrated using the $\mathrm{C} 1 \mathrm{~s}$ spectral line, due to adventitious carbon, at $285 \mathrm{eV}$.

\section{Data analysis}

We used $\mathrm{R}$ for data analysis and visualization, ${ }^{31}$ along with a collection of widely used contributed packages. ${ }^{32-35}$

\section{Paired comparisons of lead levels at the point of use}

Paired measurements collected at the point of use in October and February were compared using a parametric test of mean difference for censored data, using the cen_paired() function in the NADA2 package ${ }^{36}$ (Censoring here refers to lead concentrations below the reporting limit.) Duplicate measurements at sites within a single group were averaged; when one was observed and one censored, the duplicate measurements were re-censored at the midpoint value. Due to a log transformation of the data, back-transformed group differences are expressed as ratios. $R$ code required to reproduce the analysis is provided as Supplementary Text S2, and data are available at doi.org/10.5281/zenodo.5139734.

\section{Equilibrium lead solubility modeling}

We modeled equilibrium lead solubility using tidyphreeqc, ${ }^{37}$ an $\mathrm{R}$ interface for PHREEQC, ${ }^{38}$ and pbcusol, ${ }^{39}$ an extension of tidyphreeqc. Thermodynamic data relevant to the lead-water-carbonate-orthophosphate system were sourced from Schock et al. ${ }^{40}$ (Table S4), and activity coefficients were calculated as described in Parkhurst and Appelo. ${ }^{38}$ Model inputs were $\mathrm{pH}$, orthophosphate, and dissolved inorganic carbon concentration, calculated from $\mathrm{pH}$ and alkalinity. ${ }^{41}$ We assumed that lead solubility was controlled by hydroxypyromorphite, a mineral that has been identified in lead pipe corrosion scale recovered from the distribution system described here. ${ }^{42}$

While polyphosphate-dosed at the treatment plant at approximately $0.04 \mathrm{mg} \mathrm{P} \mathrm{L}^{-1}$-is known to form soluble complexes with lead, we did not identify lead-polyphosphate complexation at the point of use via SEC-ICP-MS..$^{20,42}$ For this reason, we opted not to include polyphosphate in the solubility model. (Lead-polyphosphate complexes were 
evident by the same method in another distribution system, at a higher polyphosphate dose of approximately $0.2 \mathrm{mg} \mathrm{P} \mathrm{L}^{-1} .42$ )

Since there were not enough paired distribution system data to include aluminum in the model, we fit a separate model to account for aluminum's effect. We calculated hydroxypyromorphite solubility on a grid of orthophosphate and aluminum concentrations at $\mathrm{pH} 7.5$ and $5 \mathrm{mg} \mathrm{L}^{-1}$ of dissolved inorganic carbon, assuming that both hydroxypyromorphite and variscite $\left(\mathrm{AIPO}_{4} \cdot 2 \mathrm{H}_{2} \mathrm{O}\right)$ reached equilibrium with the solution. Thermodynamic data describing variscite dissolution and two aqueous aluminum phosphate species were sourced from Roncal-Herrero and Oelkers, ${ }^{43}$ and $\mathrm{R}$ code to reproduce the analysis is included as Supplementary Text S3.

\section{Distribution system monitoring data}

We fit generalized additive models (equations $1-2)^{44,45}$ to a compiled dataset comprising fully-flushed residential samples, distribution system monitoring samples, and treated water samples collected at the water supply plant. We restricted our analysis to the period when a nominal orthophosphate concentration of $0.5 \mathrm{mg} \mathrm{PO}_{4} \mathrm{~L}^{-1}$ was dosed to the system (2003-2016, P dosed as a 3:1 ortho:polyphosphate blend). Time series included between 10 and 366 measurements per year.

Generalized additive models included a multi-year trend, a seasonal trend, and an autoregressive error term. ${ }^{46}$ The multi-year trend was estimated using a thin plate regression spline and the seasonal trend using a cyclic cubic regression spline. ${ }^{44}$ We fit separate cyclic splines to orthophosphate data collected at the treatment plant and in the distribution system, and we included a parametric term to model the difference in orthophosphate residual between these two groups. The autoregressive error term was second order in the models fitted to the temperature and orthophosphate product dose series and continuous-time first-order otherwise. Equation (1) describes the basic model.

$$
\text { (1) } y=\beta_{0}+f_{\text {trend }}\left(t_{1}\right)+f_{\text {seasonal }}\left(t_{2}\right)+\epsilon
$$


In equation (1), $y$ is the response, $t_{1}$ is the numeric date, $t_{2}$ is the day of the year, $\beta_{0}$ is the intercept, $\epsilon$ is the error term, and the $f(t)$ are linear combinations of basis functions (equation 2).

$$
\text { (2) } f(t)=\sum_{j=1}^{k} b_{j}(t) \beta_{j}
$$

In equation (2), $\beta_{j}$ is the weight associated with the $j$ th basis function. The weighted basis functions $b_{j}(t) \beta_{j}$ comprising each model-and their sums, the fitted values-are shown in Figure S2-S4. While the utility data are confidential, we have included the code used to generate the models in Supplementary Text S4, along with a simulated dataset. Models are further summarized in Table S5; residuals were approximately Gaussian (Figure S5), homoscedastic (Figure S6-S7), and largely free from autocorrelation (Figure S8).

\section{Static corrosion cell data}

We fit a linear regression model to the $2^{3}$ factorial coupon study after a natural log transformation of the response, as described in Montgomery. ${ }^{47}$ Model residuals were approximately Gaussian and homoscedastic (Figure S9). A response surface was generated by predicting from the model over a grid of aluminum concentrations, orthophosphate concentrations, and water temperatures. $\mathrm{R}$ code to reproduce the results is provided as Supplementary Text S5 and experimental data are available at doi.org/10.5281/zenodo.5139734.

\section{Results and discussion}

\section{Aluminum and orthophosphate seasonality in the distribution system}

Aluminum levels were strongly seasonal in the distribution system we studied (Figure 2). Median aluminum was highest in February and lowest in July: 182 and $32 \mu \mathrm{g} \mathrm{L}^{-1}$ respectively. The aluminum residual in treated water is generally highest when water temperature is lowest, ${ }^{21}$ due largely to the inverse temperature dependence of 
aluminum hydroxide solubility at the median coagulation $\mathrm{pH}$ of $5.75 .{ }^{6,48,49}$ Median water temperature in these two months was 5 and $20^{\circ} \mathrm{C}$.

a
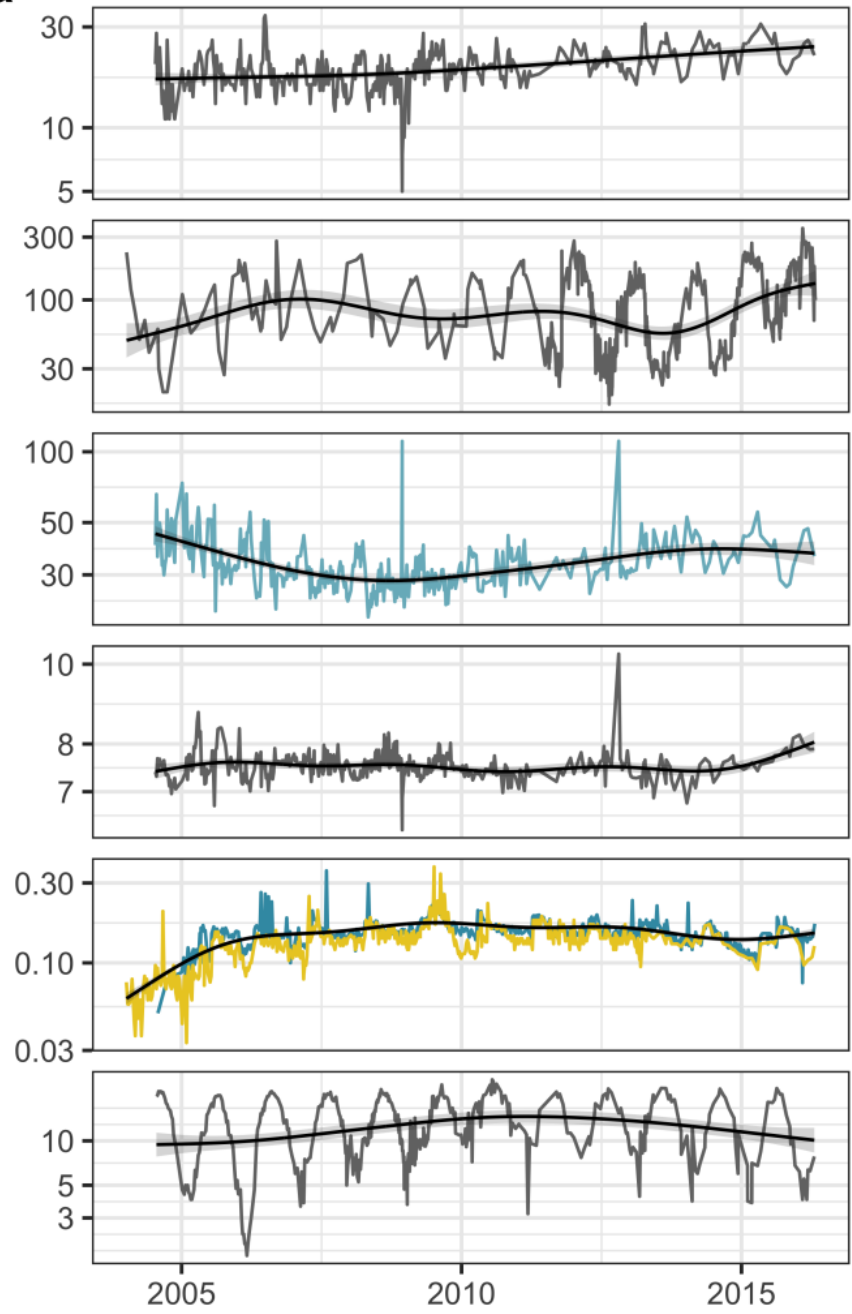

b
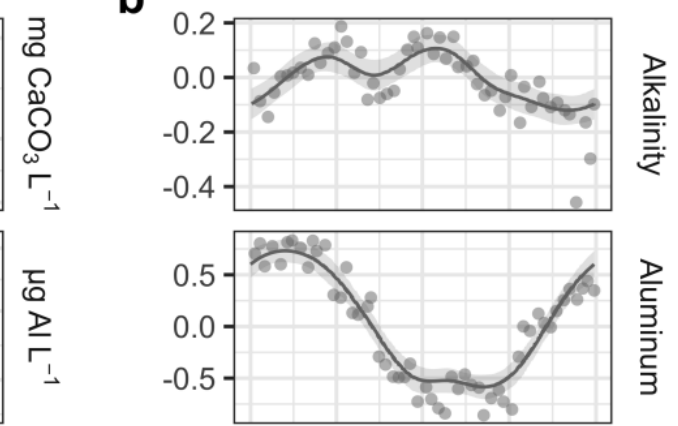

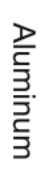
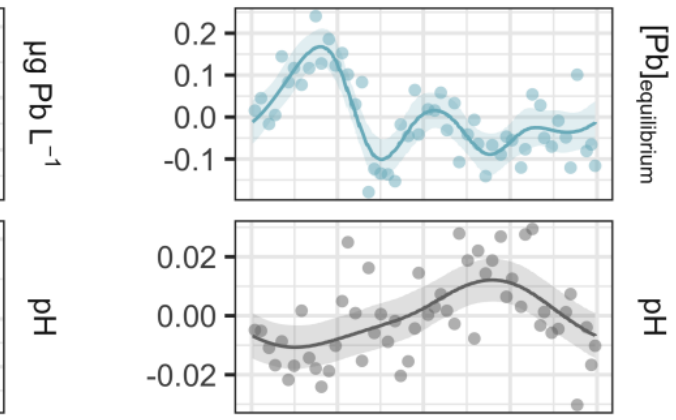

모

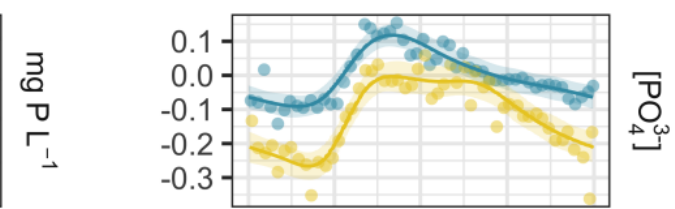

0
08
00
0
0
0
0
0

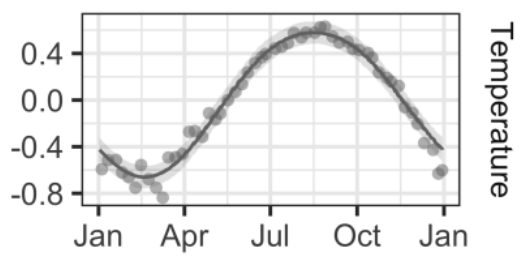

Combined $=$ Predicted $=$ Source $=$ Tap

Figure 2. (a) Mean alkalinity (as $\mathrm{CaCO}_{3}$ ), aluminum, predicted soluble lead, $\mathrm{pH}$, aqueous orthophosphate, and water temperature by date. Due to orthophosphate demand in the distribution system, data are separated by sample location: source (treatment plant) or tap (distribution system). Source and tap are combined in the series representing alkalinity, aluminum, $\mathrm{pH}$, predicted lead, and temperature. The long-term smooth component of the additive fit to the data is superimposed. (b) The seasonal component of each additive model, along with the partial residuals representing the differences between the data and the nonseasonal components of the model, aggregated into weekly means. Both the data and the model are displayed on the transformed scale. Shaded regions represent point-wise 95\% confidence intervals on the fitted values. 
Orthophosphate also exhibited a seasonal pattern. This is due primarily to variation in the applied corrosion inhibitor dose (Figure S10), but seasonal variation in the reversion rate of polyphosphate may have also been a factor. ${ }^{50}$ Minimum and maximum orthophosphate concentrations occurred in February and May respectively (130 and $170 \mu \mathrm{P} \mathrm{L} \mathrm{L}^{-1}$ ), approximately opposite those of aluminum (Figure $2 \mathrm{~b}$ ). Orthophosphate was $11 \%$ lower in the distribution system compared to the treatment plant, as estimated by a parametric term in the generalized additive model (Table S5). Aluminum precipitates with orthophosphate as $\mathrm{AlPO}_{4},{ }^{5}$ which may contribute to this difference and to the seasonal pattern in the distribution system. Alkalinity exhibited a bimodal seasonal pattern, with maxima in March and July and a minimum in December, while seasonal maximum and minimum pH occurred in September and February, respectively.

\section{Seasonal variation in predicted equilibrium lead solubility}

Variation in orthophosphate, $\mathrm{pH}$, and alkalinity predicted a complex seasonal pattern in equilibrium lead solubility, with two prominent peaks (Figure $2 b$ ). The first occurred in March, corresponding to the minimum seasonal orthophosphate concentration and the first of two seasonal alkalinity maxima. The second occurred in July, corresponding to the second seasonal alkalinity maximum. Both peaks in alkalinity yielded corresponding peaks in calculated dissolved inorganic carbon (Figure S10), and at circumneutral pH, equilibrium solubility increases with dissolved inorganic carbon in the presence of orthophosphate. ${ }^{40}$ Maximum and minimum predicted lead solubility occurred in March and May, respectively, with mean concentrations of 39 and $27 \mu \mathrm{g} \mathrm{L}^{-1}$.

\section{Periodic variation in lead at the point of use}

Consistent with equilibrium solubility predictions, lead release exhibited periodicpossibly seasonal-variation concurrent with that of aluminum and opposite to that of orthophosphate. We compared lead levels in first-draw samples collected in October with those measured in February at matched sites and drinking water outlets (Figure 3). Lead release to standing water in October was an estimated $65 \%$ of that in February ( $p$ $<<0.001, n=134$, signed-rank test). Copper release exhibited a similar trend: its 
concentration in standing water in October was an estimated $67 \%$ of that in February ( $p$ $<<0.001, n=134)$. While these data represent total concentrations only, lead and copper concentrations in $0.45 \mu \mathrm{m}$ filtrate were an estimated 75 and $89 \%$ of the corresponding total concentrations in paired aliquots representing 360 samples collected as profiles from residences with full or partial lead service lines (as described in Trueman et al., ${ }^{26}$ Figure S11). This suggests that lead and copper were largely present in the system in forms smaller than $0.45 \mu \mathrm{m}$.

On a percentage basis, differences in lead release were larger than expected based on lead solubility - predicted equilibrium lead concentrations were just $8 \%$ lower in October compared with February (accounting for variation in $\mathrm{pH}$, alkalinity, and orthophosphate). This discrepancy suggests that factors not captured by the solubility model—processes involving aluminum, for instance-were important. Observed differences were probably not due to water temperature: during overnight stagnation seasonal temperature variation is significantly damped, ${ }^{51}$ and October standing sample temperatures were $113 \%$ of February sample temperatures ( $p<<0.001, n=89$, signed-rank test). If anything, this would tend to increase October lead and copper levels relative to those in February. ${ }^{52,53}$
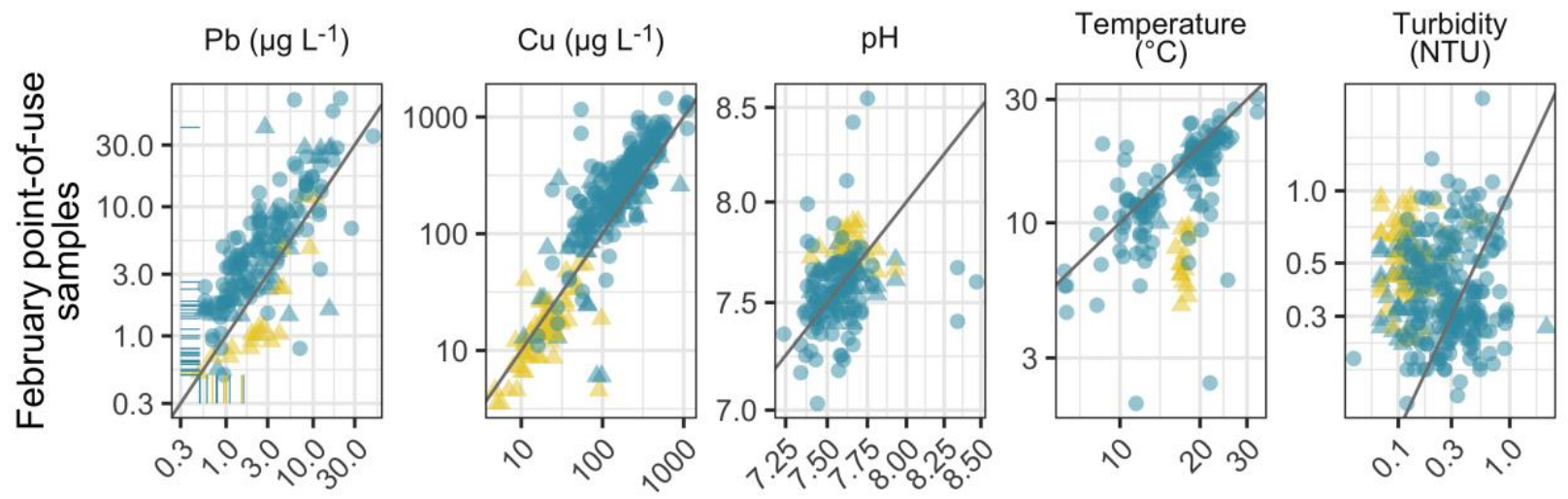

October point-of-use samples

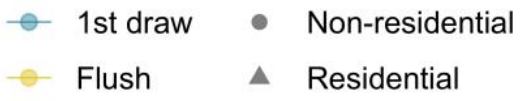


Figure 3. Lead, copper, $\mathrm{pH}$, water temperature, and turbidity at seasonally high (February) and low (October) aluminum concentrations (point-of-use samples). Grey lines represent $y=x$, and coloured vertical or horizontal lines represent left-censored lead measurements.

\section{Colloidal aluminum and lead in the distribution system}

While variation in equilibrium lead solubility probably explains at least some of the difference between October and February point-of-use lead levels, particle-generating mechanisms are also likely to be important, including partitioning of lead to particulate $(>0.45 \mu \mathrm{m})$ or colloidal $(<0.45 \mu \mathrm{m})$ aluminum. ${ }^{20,54,55}$ Particulate aluminum was seasonal in the distribution system we studied, with the median concentration in October less than half that in February (20 and $48 \mu \mathrm{g} \mathrm{L}^{-1}$, respectively, Figure $4 \mathrm{~b}$ ). The particulate fraction of total aluminum ranged from $16 \%$ in August to $35 \%$ in February, as estimated from the cyclic cubic regression splines shown in Figure $4 \mathrm{~b}$. The variation in particulate aluminum is consistent with turbidity in October being 66 and $26 \%$ of that in February in stagnant and flushed point-of-use samples, respectively $(p<<0.001$ and $<<0.001, n=$ 134 and 32 , signed-rank tests).

Seasonally-varying particulate aluminum concentrations accord with equilibrium aluminum solubility calculations at the expected distribution system water quality conditions. The aluminum hydroxide phases gibbsite $\left(\gamma-\mathrm{Al}(\mathrm{OH})_{3}\right)$, diaspore $(\alpha-\mathrm{AlOOH})$, and boehmite $(\gamma-\mathrm{AlOOH})$ are all predicted to precipitate at the seasonally-high total aluminum concentrations, and variscite $\left(\mathrm{AlPO}_{4} \cdot 2 \mathrm{H}_{2} \mathrm{O}\right)$ is predicted to precipitate seasonally at a dose of $0.5 \mathrm{mg} \mathrm{PO}_{4} \mathrm{~L}^{-1}$ (Supplementary Text S6).

Also consistent with equilibrium solubility predictions, a fraction of aluminum in $0.45 \mu \mathrm{m}$ filtrate was colloidal (Figure 4a). This fraction was sized nominally between $17 \mathrm{~nm}$-the hydrodynamic diameter of thyroglobulin (19.6 min. retention time) -and $450 \mathrm{~nm}$-the pore size at which samples were filtered. Colloids in this size range may have served as a mobile sink for lead, promoting release from corrosion scale.

Relative size distributions of lead, aluminum, and iron were typically bimodal (Figure 4a), with two incompletely resolved peaks representing colloids with different apparent molecular weights. Aluminum co-occurred with lead (and iron) in at least one of these two fractions in all samples with detectable aluminum peaks (Figures $4 \mathrm{a}$ and S1). This 
is consistent with previous work documenting adsorption of lead to aluminum hydroxides ${ }^{56-58}$ or mixed iron/aluminum (oxyhydr)oxides, ${ }^{59}$ and with previous studies reporting occurrence of lead and aluminum in a common colloid size fraction. ${ }^{20,54,55}$ The presence of aluminum, iron, and lead in distinct but overlapping colloid populations, however, cannot be ruled out completely. Moreover, these data do not provide a complete picture of colloid composition; the role of phosphorus, for example, is not clear.

a
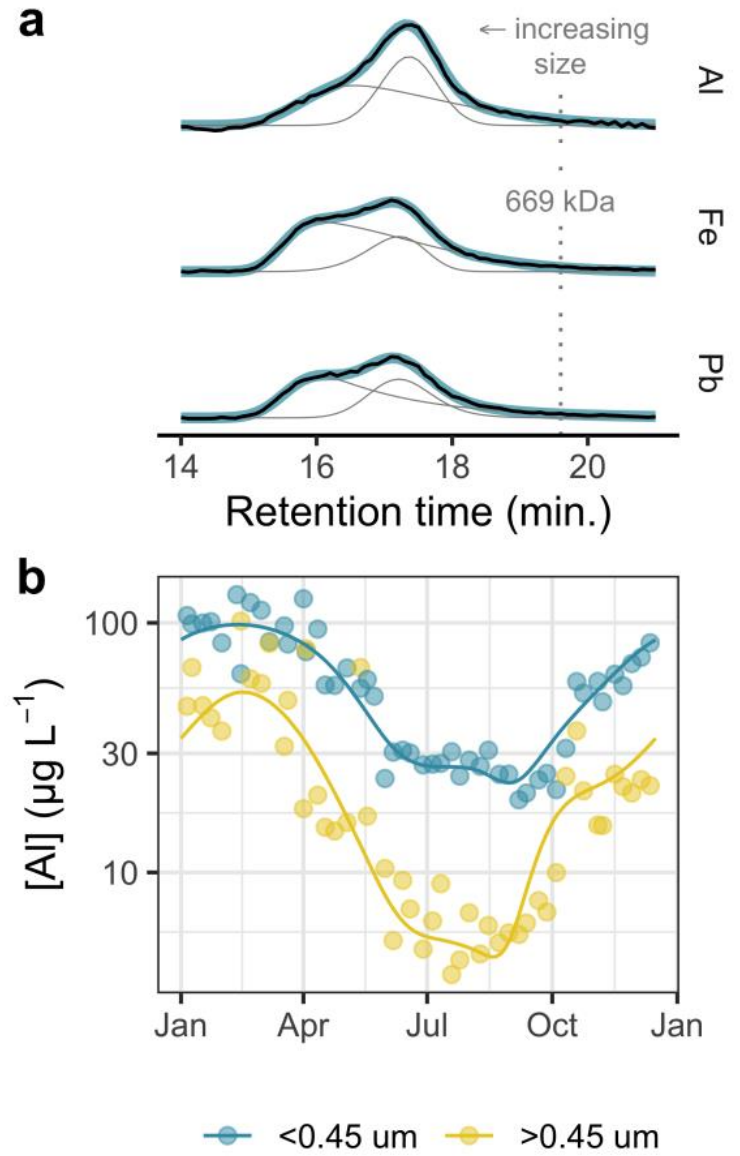

Figure 4. (a) Size-exclusion chromatograms representing the relative size distributions of aluminum, iron, and lead. Size distributions were correlated at high apparent molecular weight ( $n=16$ tap water samples representing 11 homes), and the colloidal fraction shown was sized nominally at 17-450 nm. Intensities have been normalized, baseline-corrected, and summarized as the mean intensity at each retention time. The retention time of thyroglobulin $(669 \mathrm{kDa}, 17$ $\mathrm{nm}$ diameter) is indicated by the vertical dashed line. (b) Aluminum in fully-flushed residential samples in two size fractions: greater and less than $0.45 \mu \mathrm{m}$. Data are aggregated into means 
by week of the year, and a generalized additive fit to the data with a cyclic cubic regression spline basis is superimposed.

\section{Interaction between aluminum and orthophosphate (lead coupon study)}

Distribution system monitoring data suggest that variation in both aluminum and orthophosphate may have contributed to the seasonal differences in lead release, but it is not clear which factor was more important or to what extent they acted synergistically. We evaluated these factors-along with water temperature-as predictors of lead release using a coupon study. While the effect of orthophosphate on equilibrium solubility is relatively well understood, its interactions with other species to form particles are less well characterized. ${ }^{60}$

As expected, lead release from coupons increased with water temperature. Raising the cell temperature from 4 to $21^{\circ} \mathrm{C}$ caused a $120 \%$ increase in geometric mean lead release (Figure 5a). That is, $\overline{[P b}_{21^{\circ} \mathrm{C}} / \overline{[P b}_{4{ }^{\circ} \mathrm{C}}-1=1.2$. But while temperaturedependent lead release has been described elsewhere, ${ }^{26,61}$ the solubilities of several common lead minerals do not appear to be temperature-sensitive..$^{52}$ It is not clear whether changes in solubility, dissolution, complex formation, or particle mobility are primarily responsible for temperature-driven seasonality. ${ }^{26,40,52,61}$ 
a

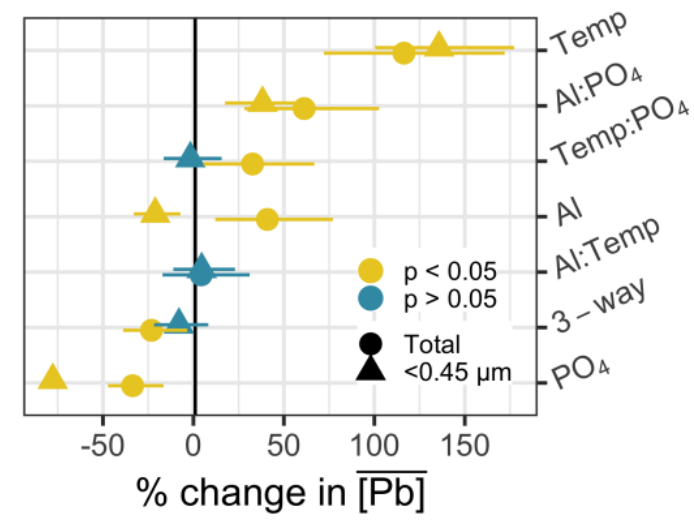

b

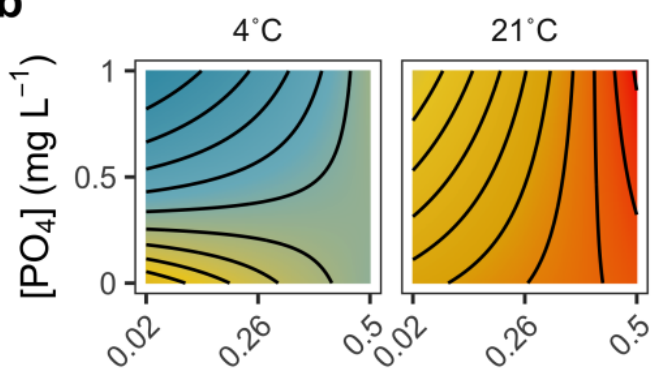

[Al] $\left(\mathrm{mg} \mathrm{L}^{-1}\right)$

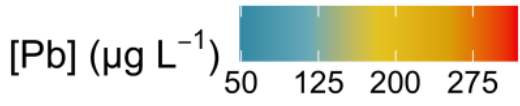

C
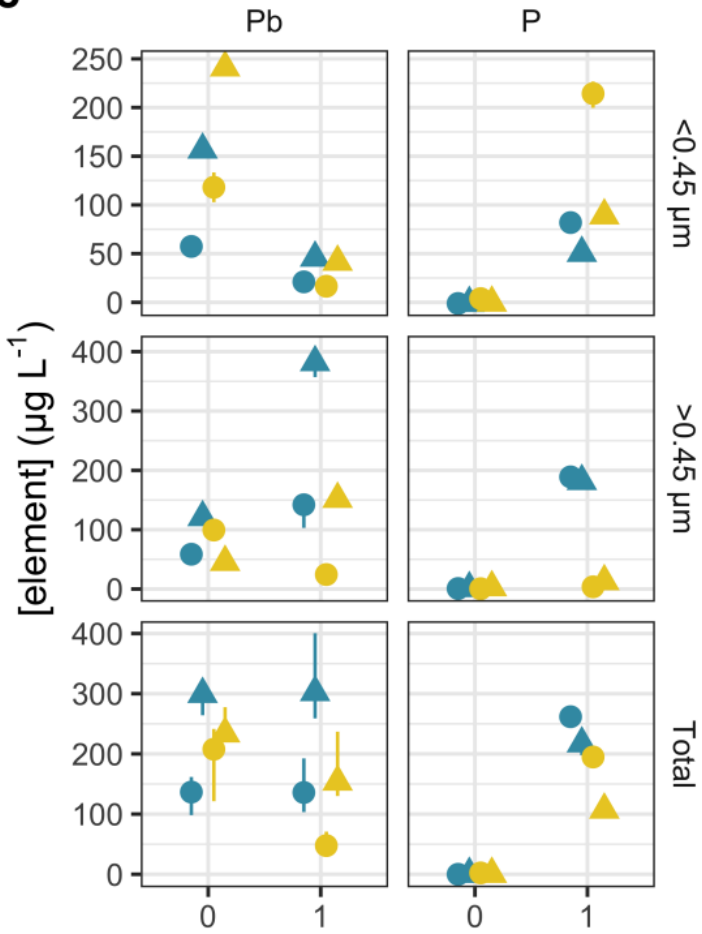

$$
\mathrm{PO}_{4} \text { dose }\left(\mathrm{mg} \mathrm{L}^{-1}\right)
$$

$[\mathrm{Al}]=500 \mu \mathrm{g} \mathrm{L}{ }^{-1}$

$[\mathrm{Al}]=20 \mu \mathrm{g} \mathrm{L}^{-1}$

- $4^{\circ} \mathrm{C} \Delta 21^{\circ} \mathrm{C}$

Figure 5. (a) Effect estimates generated by the linear model (lead coupon experiment), along with their $95 \%$ confidence intervals. (b) Predicted lead concentrations generated by applying the linear regression model to a grid of inputs (aluminum, orthophosphate, temperature). (c) Median lead and phosphorus in corrosion cells as a function of temperature, aluminum concentration, and orthophosphate dose. Error bars span the interquartile range.

Adding $1 \mathrm{mg} \mathrm{PO}_{4} \mathrm{~L}^{-1}$ decreased total lead release by 34\% (Figure 5a), while aluminum had the opposite effect; increasing the aluminum concentration from 20 to $500 \mu \mathrm{g} \mathrm{L}^{-1}$ increased total lead release by $41 \%$. Adding orthophosphate and increasing aluminum concentration accompanied a further $61 \%$ increase in lead. That is, the combined effect of aluminum and orthophosphate was larger than would be expected based on the main effect of each factor. This may be due to formation of particulate aluminum and phosphorus-perhaps as aluminum phosphate. Particulate phosphorus was highest at the high aluminum level, and in this form it would presumably be less available to react with lead in a way that immobilized lead at the scale-water interface (Figure $5 c$ and 
Figure S12). Consistent with this interpretation, substantially less phosphorus was lost to the system at the high aluminum level (i.e., more remained in the water phase). Particulate lead was also greatest at the high aluminum and orthophosphate levels (Figure $5 \mathrm{c}$ ), which may be due to partitioning of lead to precipitated aluminum phosphate.

With lead in $0.45 \mu \mathrm{m}$ filtrate as the response, several effect estimates in the linear model were notably different. Adding orthophosphate, for instance, caused a much larger percentage decrease in filtrate lead levels (78\%, Figure 5a). This is consistent with orthophosphate's expected effect on lead solubility, while effective control of particulate lead by orthophosphate requires that lead phosphate precipitates become immobilized in corrosion scale. Here, $\mathrm{P}: \mathrm{Pb}$ molar ratios were much greater than one, a threshold that has been noted previously to promote formation of dispersed lead phosphate particles. ${ }^{60}$ And in addition to the effect of aluminum in boosting particulate lead concentrations, the dispersive effect of orthophosphate may be especially pronounced at the relatively low hardness characteristic of our experimental water (3.9 $\mathrm{mg} \mathrm{CaCO}_{3} \mathrm{~L}^{-1}$, Table S2). Orthophosphate-induced dispersion is also enhanced in the presence of humic and fulvic acids. ${ }^{60}$ And while coagulation here would have removed the majority of the hydrophobic acid fraction, ${ }^{62}$ natural organic matter may still have played a role in dispersing particulate lead. ${ }^{63}$

In contrast to its effect on total lead release, aluminum decreased lead in filtrate by $21 \%$ (Figure 5a, neglecting the aluminum-orthophosphate interaction). This agrees with previous work suggesting that aluminum may promote formation of a diffusion barrier on lead composed of aluminum hydroxide, silicate, or other compounds. ${ }^{11}$ Alternatively, aluminum may have facilitated partitioning of soluble lead to suspended particles, shifting the size distribution of lead in the test waters.

\section{Coupon corrosion scale}

We characterized the corrosion scale that formed on coupons under all experimental conditions using XRD (Table S1). As expected, hydroxypyromorphite formed in the presence of orthophosphate, while hydrocerussite $\left(\mathrm{Pb}_{3}\left(\mathrm{CO}_{3}\right)_{2}(\mathrm{OH})_{2}\right)$ was identified in 
scale from all sample coupons. Massicot $(\beta-\mathrm{PbO})$ was also universally present, but the intensities of the (111) and (200) peaks at 29.1 and $30.3^{\circ}$, respectively, were not consistent with the standard pattern. This may have been due to preferential orientation of crystallites on the coupon surfaces.
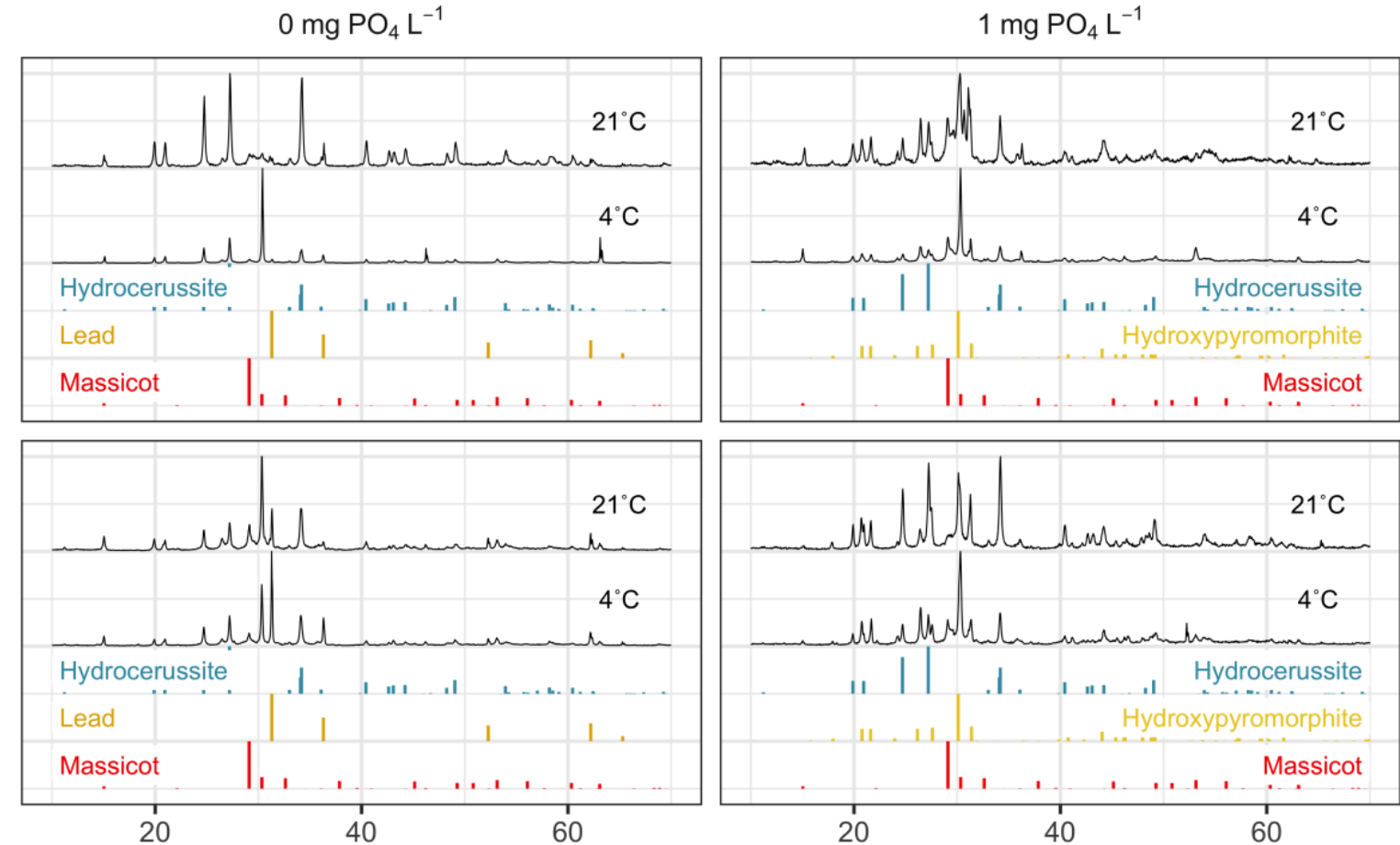

\begin{tabular}{l}
0 \\
8 \\
0 \\
0 \\
$D$ \\
$ㄷ$ \\
\hline
\end{tabular}

Hydrocerussite

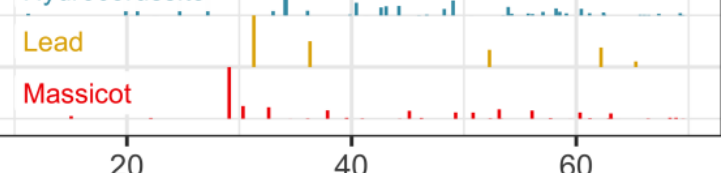

$2 \theta(\mathrm{Cu} \mathrm{K} \alpha)$

- Hydrocerussite - Hydroxypyromorphite - Lead - Massicot

Figure 6. XRD patterns representing corrosion scale on lead coupons at each treatment combination. Intensities are scaled to a $[0,1]$ interval in all patterns and standards.

Aluminum was not identified in any crystalline mineral forms by $\mathrm{XRD}$, and the experimental patterns representing coupons exposed to 20 and $500 \mu \mathrm{g} \mathrm{Al} \mathrm{L}^{-1}$ were similar (Figure 6). Moreover, aluminum was not detectable by XPS in the top few nanometers of corrosion scale exposed to the high level of aluminum ( $\left.0.5 \mathrm{mg} \mathrm{Al} \mathrm{L}^{-1}\right)$ (Figure S13). Thus it is likely that the aluminum content of scale was relatively low, although XPS detection limits for light elements (e.g., Al) in a heavy element matrix (e.g., $\mathrm{Pb}$ ) tend to be above 1 atomic percent. ${ }^{64}$ 
The low surface concentration of aluminum is consistent with our interpretation that aluminum acted primarily by promoting particulate lead formation and limiting the activity of orthophosphate in solution. Moreover, the mineralogy of the scale, as determined by XRD, was predictable without considering the aluminum concentration. On the longer time scales relevant to drinking water distribution, however, aluminum may alter lead corrosion scale in a way that impacts lead release. Here, the apparent effect of aluminum in limiting dissolved lead release in the absence of orthophosphate was relatively small, and it was not due to readily discernable differences in coupon scale at the high and low aluminum levels.

\section{Modeling aluminum-phosphate interactions}

Key findings from the coupon study — high lead release from and inhibited phosphorus uptake by corrosion scale in the presence of aluminum-agree well with a previous report that aluminum interferes with orthophosphate corrosion control. ${ }^{14}$ Given the results we report, this is likely due to both increased solubility and particle-generating mechanisms. And while the full picture is complex, the effect of aluminum on lead solubility—neglecting particles and surfaces—can be modeled by allowing coprecipitation of aluminum and orthophosphate (here as variscite, $\mathrm{AlPO}_{4} \cdot 2 \mathrm{H}_{2} \mathrm{O}$ ) in the presence of hydroxypyromorphite (Figure 7). We applied this model over a grid of aluminum and orthophosphate concentrations (Figure $7 a$ and $b$ ) and, neglecting other sources of variation, to the aluminum concentrations measured in the distribution system (Figure 7c). Consistent with the experimental results, aluminum phosphate precipitation increased lead solubility by decreasing the concentration of orthophosphate in solution. This was predicted to occur except at very low aluminum concentrations (e.g., approximately $50 \mu \mathrm{g} \mathrm{Al} \mathrm{L}^{-1}$ at $1 \mathrm{mg} \mathrm{PO}_{4} \mathrm{~L}^{-1}$, Figure $7 \mathrm{~b}$ ). And at the aluminum concentrations characteristic of the distribution system, significant seasonal variation in lead solubility is predicted (Figure 7c). 

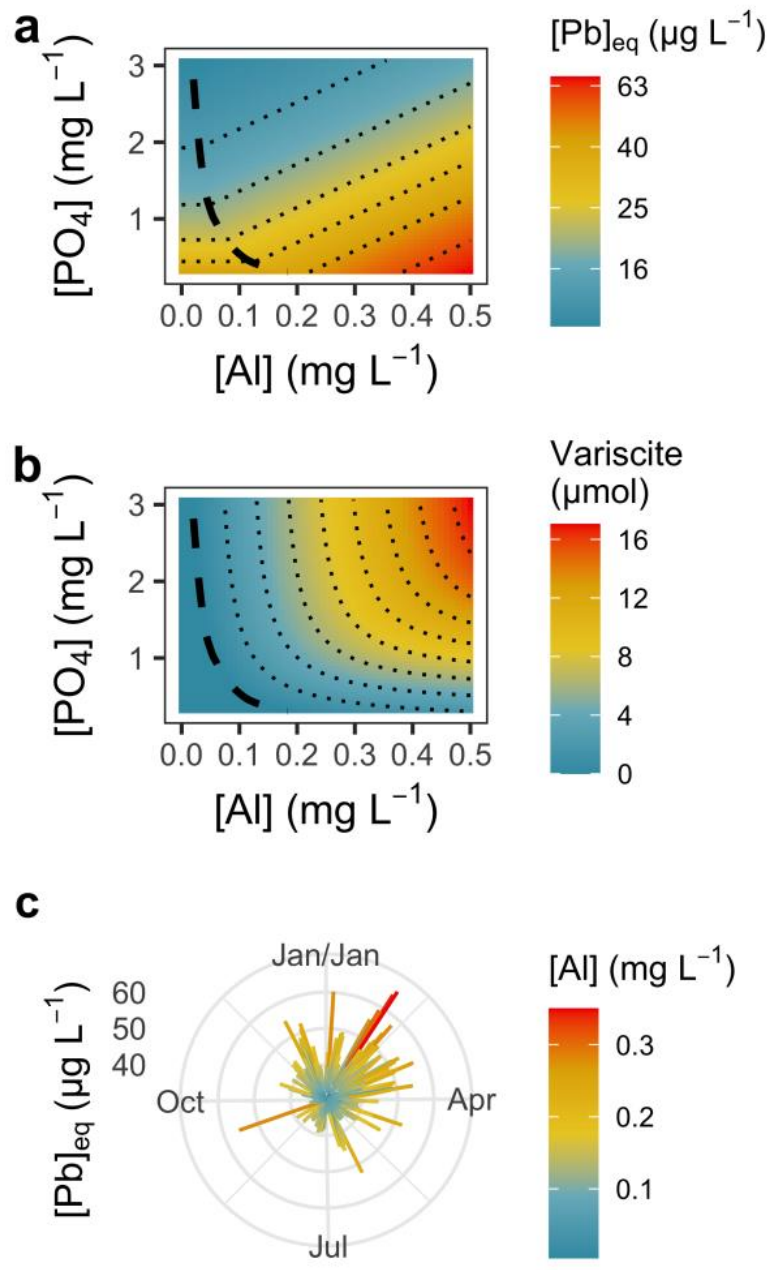

Figure 7. (a) Predicted lead solubility due to dissolution of hydroxypyromorphite, evaluated on a grid of orthophosphate and aluminum concentrations at $\mathrm{pH} 7.3$ with $5 \mathrm{mg} \mathrm{L}^{-1}$ of dissolved inorganic carbon. (b) Precipitated variscite, $\mathrm{AlPO}_{4} \cdot 2 \mathrm{H}_{2} \mathrm{O}$, at equilibrium under the same conditions. In (a) and (b), heavy dashed lines represent approximate variscite saturation. (c) Predicted lead solubility by day of the year, using distribution system aluminum data, $\mathrm{pH} 7.3,5$ $\mathrm{mg} \mathrm{L}^{-1}$ of dissolved inorganic carbon, and $0.5 \mathrm{mg} \mathrm{PO}_{4} \mathrm{~L}^{-1}$ as inputs. N.B., one anomalously high record with $0.96 \mathrm{mg} \mathrm{Al} \mathrm{L}^{-1}$ is omitted from the plot.

\section{Conclusions}

We identified an apparent seasonal pattern in lead release to orthophosphate-treated drinking water via point of use sampling. And while variation in orthophosphate, $\mathrm{pH}$, and alkalinity predicted a similar pattern in equilibrium lead solubility, seasonal variation in aluminum may have also been a factor, given its strong correspondence with observed 
lead levels. In a follow-up coupon corrosion study, aluminum increased total lead release significantly. As expected, orthophosphate decreased lead release, but high levels of aluminum and orthophosphate together resulted in greater lead release than would be predicted based on the main effects of these two factors. We suggest that the interference of orthophosphate corrosion control by aluminum is due largely to precipitation of aluminum phosphate. This reaction limits the activity of orthophosphate and may provide a surface to which soluble lead can partition-increasing the total lead content of drinking water.

Our data suggest that treatment facilities applying aluminum-based coagulants should ensure that residual aluminum in treated water remains low to limit seasonal variation in the performance of orthophosphate. In the water system we studied, a recent increase in coagulation $\mathrm{pH}$ to 6.2 has decreased the median April aluminum concentration at the treatment plant by a factor of more than four relative to the 2003-2016 study period. At the more recent concentrations, predicted aluminum phosphate precipitation is minimal $(<1 \mu \mathrm{mol})$, even at a higher orthophosphate dose of $1 \mathrm{mg} \mathrm{PO}_{4} \mathrm{~L}^{-1}$. The predicted effect of aluminum on equilibrium lead solubility, then, is also much smaller.

More generally, aluminum-orthophosphate-lead interactions highlight an important connection between corrosion control and the treatment process, potentially involving the soluble, colloidal, and particulate fractions of these elements.

\section{Acknowledgements}

We acknowledge the financial and technical support provided by Halifax Water through the NSERC/Halifax Water Industrial Research Chair program (Grant no. IRCPJ: 349838-16) and the technical support provided by Heather Daurie, Andrew George, Caitlin Sampson, and Halifax Water staff. 


\section{Supporting information}

Individual SEC chromatograms; details of the generalized additive models fit to water quality time series; additional desription of the coupon study; $R$ code to reproduce the water quality data analysis and the geochemical models.

\section{References}

(1) Dignam, T.; Kaufmann, R. B.; LeStourgeon, L.; Brown, M. J. Control of Lead Sources in the United States, 1970-2017: Public Health Progress and Current Challenges to Eliminating Lead Exposure. J. Public Health Manag. Pract. 2019, 25 (1), S13-S22. https://doi.org/10.1097/PHH.0000000000000889.

(2) Zahran, S.; McElmurry, S. P.; Sadler, R. C. Four Phases of the Flint Water Crisis: Evidence from Blood Lead Levels in Children. Environ. Res. 2017, 157, 160-172. https://doi.org/10.1016/j.envres.2017.05.028.

(3) Colling, J. H.; Whincup, P. A. E.; Hayes, C. R. The Measurement of Plumbosolvency Propensity to Guide the Control of Lead in Tapwaters. Water Environ. J. 1987, 1 (3), 263-269. https://doi.org/10.1111/j.1747-

6593.1987.tb01224.x.

(4) Health Canada. Guidelines for Canadian Drinking Water Quality: Guideline Technical Document, Lead.; 2019.

(5) Frommell, D. M.; Feld, C. M.; Snoeyink, V. L.; Melcher, B.; Feizoulof, C. Aluminum Residual Control Using Orthophosphate. J. Am. Water Works Assoc. 2004, 96 (9), 99-109. https://doi.org/10.1002/j.1551-8833.2004.tb10707.x.

(6) Pernitsky, D. J.; Edzwald, J. K. Selection of alum and polyaluminum coagulants: principles and applications. J. Water Supply Res. Technol. AQUA 2006, 55 (2), $121-141$.

(7) Health Canada. Aluminum in Drinking Water: Guideline Technical Document for Consultation, 2019.

(8) Mishrra, A.; Wang, Z.; Sidorkiewicz, V.; Giammar, D. E. Effect of Sodium Silicate on Lead Release from Lead Service Lines. Water Res. 2021, 188, 116485. https://doi.org/10.1016/j.watres.2020.116485.

(9) Kim, E. J.; Herrera, J. E.; Huggins, D.; Braam, J.; Koshowski, S. Effect of pH on the Concentrations of Lead and Trace Contaminants in Drinking Water: A Combined Batch, Pipe Loop and Sentinel Home Study. Water Res. 2011, 45 (9), 2763-2774. https://doi.org/10.1016/j.watres.2011.02.023. 
(10) Zhang, Y.; Shi, B.; Zhao, Y.; Yan, M.; Lytle, D. A.; Wang, D. Deposition Behavior of Residual Aluminum in Drinking Water Distribution System: Effect of Aluminum Speciation. J. Environ. Sci. 2016, 42, 142-151.

https://doi.org/10.1016/j.jes.2015.05.010.

(11) Snoeyink, V. L.; Schock, M. R.; Sarin, P.; Wang, L.; Chen, A. S.-C.; Harmon, S. M. Aluminium-Containing Scales in Water Distribution Systems: Prevalence and Composition. J. Water Supply Res. Technol. AQUA 2003, 52 (7), 455-474. https://doi.org/10.2166/aqua.2003.0042.

(12) Kvech, S.; Edwards, M. Role of Aluminosilicate Deposits in Lead and Copper Corrosion. J. Am. Water Works Assoc. 2001, 93 (11), 104-112.

https://doi.org/10.1002/j.1551-8833.2001.tb09339.x.

(13) Holmes, H. Probing the Role of Silicates for Corrosion Control in Lead Plumbing. PhD thesis, The University of Western Ontario, 2021.

(14) Li, G.; Bae, Y.; Mishrra, A.; Shi, B.; Giammar, D. E. Effect of Aluminum on Lead Release to Drinking Water from Scales of Corrosion Products. Environ. Sci. Technol. 2020, 54 (10), 6142-6151. https://doi.org/10.1021/acs.est.0c00738.

(15) Crawford, Harold B. Water quality and treatement: a handbook of community water supplies, 4th ed.; McGraw Hill: Washington, DC, 1990.

(16) Wasserstrom, L. W.; Miller, S. A.; Triantafyllidou, S.; Desantis, M. K.; Schock, M. R. Scale Formation Under Blended Phosphate Treatment for a Utility With Lead Pipes. J. Am. Water Works Assoc. 2017, 109, E464-E478.

https://doi.org/10.5942/jawwa.2017.109.0121.

(17) Doré, E.; Deshommes, E.; Laroche, L.; Nour, S.; Prévost, M. Study of the LongTerm Impacts of Treatments on Lead Release from Full and Partially Replaced Harvested Lead Service Lines. Water Res. 2019, 149, 566-577.

https://doi.org/10.1016/j.watres.2018.11.037.

(18) Doré, E.; Deshommes, E.; Laroche, L.; Nour, S.; Prévost, M. Lead and Copper Release from Full and Partially Replaced Harvested Lead Service Lines: Impact of Stagnation Time Prior to Sampling and Water Quality. Water Res. 2019, 150, 380-391. https://doi.org/10.1016/j.watres.2018.11.076.

(19) Mora, S. J. de; Harrison, R. M.; Wilson, S. J. The Effect of Water Treatment on the Speciation and Concentration of Lead in Domestic Tap Water Derived from a Soft Upland Source. Water Res. 1987, 21 (1), 83-94.

https://doi.org/10.1016/0043-1354(87)90102-3.

(20) Trueman, B. F.; Gagnon, G. A. A New Analytical Approach to Understanding Nanoscale Lead-Iron Interactions in Drinking Water Distribution Systems. J. Hazard. Mater. 2016, 311, 151-157.

https://doi.org/10.1016/j.jhazmat.2016.03.001. 
(21) Knowles, A. D.; Nguyen, C. K.; Edwards, M. A.; Stoddart, A.; Mcllwain, B.; Gagnon, G. A. Role of Iron and Aluminum Coagulant Metal Residuals and Lead Release from Drinking Water Pipe Materials. J. Environ. Sci. Health. Part A Environ. Sci. Eng. 2015, 50 (4), 414-423. https://doi.org/10.1080/10934529.2015.987550.

(22) USEPA. Method 310.2: Alkalinity (Colorimetric, Automated, Methyl Orange) by Autoanalyzer; 1974.

(23) USEPA. Method 6020b (SW-846): Inductively Coupled Plasma-Mass Spectrometry, Revision 2.; 2014.

(24) American Public Health Association, W. E. F., American Water Works Association. 4500-p PHOSPHORUS. In Standard methods for the examination of water and wastewater; 2018.

(25) Mcllwain, B. Investigating sources of elevated lead in drinking water. Master's thesis, Dalhousie University, 2013.

(26) Trueman, B. F.; Camara, E.; Gagnon, G. A. Evaluating the Effects of Full and Partial Lead Service Line Replacement on Lead Levels in Drinking Water. Environ. Sci. Technol. 2016, 50 (14), 7389-7396. https://doi.org/10.1021/acs.est.6b01912.

(27) American Public Health Association. 3125 METALS BY INDUCTIVELY COUPLED PLASMA-MASS SPECTROMETRY (2017). In Standard methods for the examination of water and wastewater; 2018.

(28) Trueman, B. fffprocessr: Process FFF-UV-MALS-ICP-MS data https://github.com/bentrueman/fffprocessr.

(29) Trueman, B. F.; Anaviapik-Soucie, T.; L’Hérault, V.; Gagnon, G. A. Characterizing Colloidal Metals in Drinking Water by Field Flow Fractionation. Environ. Sci. Water Res. Technol. 2019, 5 (12), 2202-2209. https://doi.org/10.1039/C9EW00560A.

(30) American Public Health Association. 5310 TOTAL ORGANIC CARBON (TOC) (2017). In Standard Methods For the Examination of Water and Wastewater; Standard Methods for the Examination of Water and Wastewater; 2018.

(31) R Core Team. R: A language and environment for statistical computing https://www.R-project.org/.

(32) Wickham, H. tidyverse: Easily install and load the 'tidyverse' https://tidyverse.tidyverse.org/.

(33) Ram, K.; Wickham, H. Wesanderson: A wes anderson palette generator https://CRAN.R-project.org/package=wesanderson.

(34) Grolemund, G.; Wickham, H. Dates and Times Made Easy with Lubridate. J. Stat. Soft. 2011, 40 (3). https://doi.org/10.18637/jss.v040.i03. 
(35) Allaire, J.; Xie, Y.; McPherson, J.; Luraschi, J.; Ushey, K.; Atkins, A.; Wickham, H.; Cheng, J.; Chang, W.; lannone, R. rmarkdown: Dynamic documents for R https://github.com/rstudio/rmarkdown.

(36) Julian, P.; Helsel, D. NADA2: Data analysis for censored environmental data. https://CRAN.R-project.org/package=NADA2.

(37) Dunnington, D. tidyphreeqc: Tidy geochemical modeling using PHREEQC https://github.com/paleolimbot/tidyphreeqc.

(38) Parkhurst, D. L.; Appelo, C. A. J. Description of Input and Examples for PHREEQC Version 3-a Computer Program for Speciation, Batch-Reaction, OneDimensional Transport, and Inverse Geochemical Calculations; Techniques and methods; U.S. Geological Survey, 2013; Vol. book 6, p 497.

(39) Trueman, B. pbcusol: Predict lead and copper solubility https://github.com/bentrueman/pbcusol.

(40) Schock, M. R.; Wagner, I.; Oliphant, R. J. Corrosion and solubility of lead in drinking water. In Internal corrosion of water distribution systems; American Water Works Association Research Foundation: Denver, CO, 1996; pp 131-230.

(41) Schock, M. R. Response of Lead Solubility to Dissolved Carbonate in Drinking Water. J. Am. Water Works Assoc. 1980, 72 (12), 695-704. https://doi.org/10.1002/j.1551-8833.1980.tb04616.x.

(42) Trueman, B. F.; Krkošek, W. H.; Gagnon, G. A. Effects of Ortho- and Polyphosphates on Lead Speciation in Drinking Water. Environ. Sci. Water Res. Technol. 2018, 4 (4), 505-512. https://doi.org/10.1039/C7EW00521K.

(43) Roncal-Herrero, T.; Oelkers, E. H. Does Variscite Control Phosphate Availability in Acidic Natural Waters? An Experimental Study of Variscite Dissolution Rates. Geochim. Cosmochim. Acta 2011, 75 (2), 416-426. https://doi.org/10.1016/j.gca.2010.10.012.

(44) Wood, S. N. Generalized Additive Models: An Introduction with r, 2nd ed.; Chapman; Hall/CRC, 2017.

(45) Simpson, G. L. gratia: Graceful 'ggplot'-based graphics and other functions for GAMs fitted using 'mgcv' https://gavinsimpson. github.io/gratia/.

(46) Pinheiro, J.; Bates, D.; DebRoy, S.; Sarkar, D.; R Core Team. nlme: Linear and nonlinear mixed effects models https:/CRAN.R-project.org/package=nlme.

(47) Montgomery, D. C. Design and Analysis of Experiments, Eighth edition.; John Wiley \& Sons, Inc: Hoboken, NJ, 2013.

(48) Knowles, A. D.; MacKay, J.; Gagnon, G. A. Pairing a Pilot Plant to a Direct Filtration Water Treatment Plant. Can. J. Civ. Eng. 2012, 39 (6), 689-700. https://doi.org/10.1139//2012-060. 
(49) Vadasarukkai, Y. S. Investigation of the mixing energy consumption affecting coagulation and floc aggregation. PhD thesis, Dalhousie University, Halifax, Nova Scotia, 2016.

(50) Cantor, A. F.; Denig-Chakroff, D.; Vela, R. R.; Oleinik, M. G.; Lynch, D. L. Use of Polyphosphate in Corrosion Control. J. Am. Water Works Assoc. 2000, 92 (2), 95-102. https://doi.org/10.1002/j.1551-8833.2000.tb08820.x.

(51) Britton, A.; Richards, W. Factors influencing plumbsolvency in Scotland. J. Inst. Water Eng. Sci. 1981, 35, 349-364.

(52) Masters, S.; Welter, G. J.; Edwards, M. Seasonal Variations in Lead Release to Potable Water. Environ. Sci. Technol. 2016, 50 (10), 5269-5277. https://doi.org/10.1021/acs.est.5b05060.

(53) Boulay, N.; Edwards, M. Role of Temperature, Chlorine, and Organic Matter in Copper Corrosion by-Product Release in Soft Water. Water Res. 2001, 35 (3), 683-690. https://doi.org/10.1016/S0043-1354(00)00320-1.

(54) Aghasadeghi, K.; Peldszus, S.; Trueman, B. F.; Mishrra, A.; Cooke, M. G.; Slawson, R. M.; Giammar, D. E.; Gagnon, G. A.; Huck, P. M. Pilot-Scale Comparison of Sodium Silicates, Orthophosphate and pH Adjustment to Reduce Lead Release from Lead Service Lines. Water Res. 2021, 195, 116955. https://doi.org/10.1016/j.watres.2021.116955.

(55) Li, B.; Trueman, B. F.; Munoz, S.; Locsin, J. A.; Gagnon, G. A. Impact of Sodium Silicate on Lead Release and Colloid Size Distributions in Drinking Water. Water Res. 2020, 116709. https://doi.org/10.1016/j.watres.2020.116709.

(56) Kinniburgh, D. G.; Jackson, M. L.; Syers, J. K. Adsorption of Alkaline Earth, Transition, and Heavy Metal Cations by Hydrous Oxide Gels of Iron and Aluminum. Soil Sci. Soc. Am. J. 1976, 40 (5), 796-799. https://doi.org/10.2136/sssaj1976.03615995004000050047x.

(57) McBride, M. Processes of Heavy and Transition Metal Sorption by Soil Minerals. In Interactions at the soil colloid-soil solution interface; Springer, 1991; pp 149175.

(58) Saha, U. K.; Taniguchi, S.; Sakurai, K. Adsorption Behavior of Cadmium, Zinc, and Lead on Hydroxyaluminum- and Hydroxyaluminosilicate-Montmorillonite Complexes. Soil Sci. Soc. Am. J. 2001, 65 (3), 694-703. https://doi.org/10.2136/sssaj2001.653694x.

(59) Violante, A.; Ricciardella, M.; Pigna, M. Adsorption of Heavy Metals on Mixed FeAl Oxides in the Absence or Presence of Organic Ligands. Water Air Soil Pollut. 2003, 145 (1), 289-306. https://doi.org/10.1023/A:1023662728675.

(60) Zhao, J.; Giammar, D. E.; Pasteris, J. D.; Dai, C.; Bae, Y.; Hu, Y. Formation and Aggregation of Lead Phosphate Particles: Implications for Lead Immobilization in 
Water Supply Systems. Environ. Sci. Technol. 2018, 52 (21), 12612-12623. https://doi.org/10.1021/acs.est.8b02788.

(61) Cartier, C.; Laroche, L.; Deshommes, E.; Nour, S.; Richard, G.; Edwards, M.; Prévost, M. Investigating Dissolved Lead at the Tap Using Various Sampling Protocols. J. Am. Water Works Assoc. 2011, 103 (3), 55-67.

https://doi.org/10.1002/j.1551-8833.2011.tb11420.x.

(62) Korshin, G. V.; Ferguson, J. F.; Lancaster, A. N.; Wu, H. Corrosion and Metal Release for Lead-Containing Materials: Influence of NOM; AWWA Research Foundation; American Water Works Association: Denver, 1999.

(63) Liu, H.; Schonberger, K. D.; Korshin, G. V.; Ferguson, J. F.; Meyerhofer, P.; Desormeaux, E.; Luckenbach, H. Effects of Blending of Desalinated Water with Treated Surface Drinking Water on Copper and Lead Release. Water Res. 2010, 44 (14), 4057-4066. https://doi.org/10.1016/j.watres.2010.05.014.

(64) Shard, A. G. Detection Limits in XPS for More Than 6000 Binary Systems Using Al and Mg Ka X-Rays: XPS Detection Limits. Surf. Interface Anal. 2014, 46 (3), 175-185. https://doi.org/10.1002/sia.5406. 


\section{Supplementary information for Seasonal lead release to drinking water and the effect of aluminum}

Benjamin F. Trueman, ${ }^{*}, 1$ Aaron Bleasdale-Pollowy, ${ }^{1}$ Javier A. Locsin, ${ }^{1}$ Jessica L. Bennett, ${ }^{1}$ Wendy H. Krkošek, ${ }^{2}$ and Graham A. Gagnon ${ }^{1}$

${ }^{1}$ Centre for Water Resources Studies, Department of Civil \& Resource Engineering, Dalhousie University, 1360 Barrington St., Halifax, Nova Scotia, Canada B3H 4R2

${ }^{2}$ Halifax Water, 450 Cowie Hill Rd., Halifax, Nova Scotia, Canada, PO Box 8388, B3K $5 \mathrm{M} 1$

${ }^{*}$ Corresponding author

E-mail: benjamin.trueman@dal.ca

Tel: 902.494 .6070

Fax: 902.494 .3105

This document contains 14 figures, 5 tables, 6 text blocks, and 29 pages 


\section{Figures}
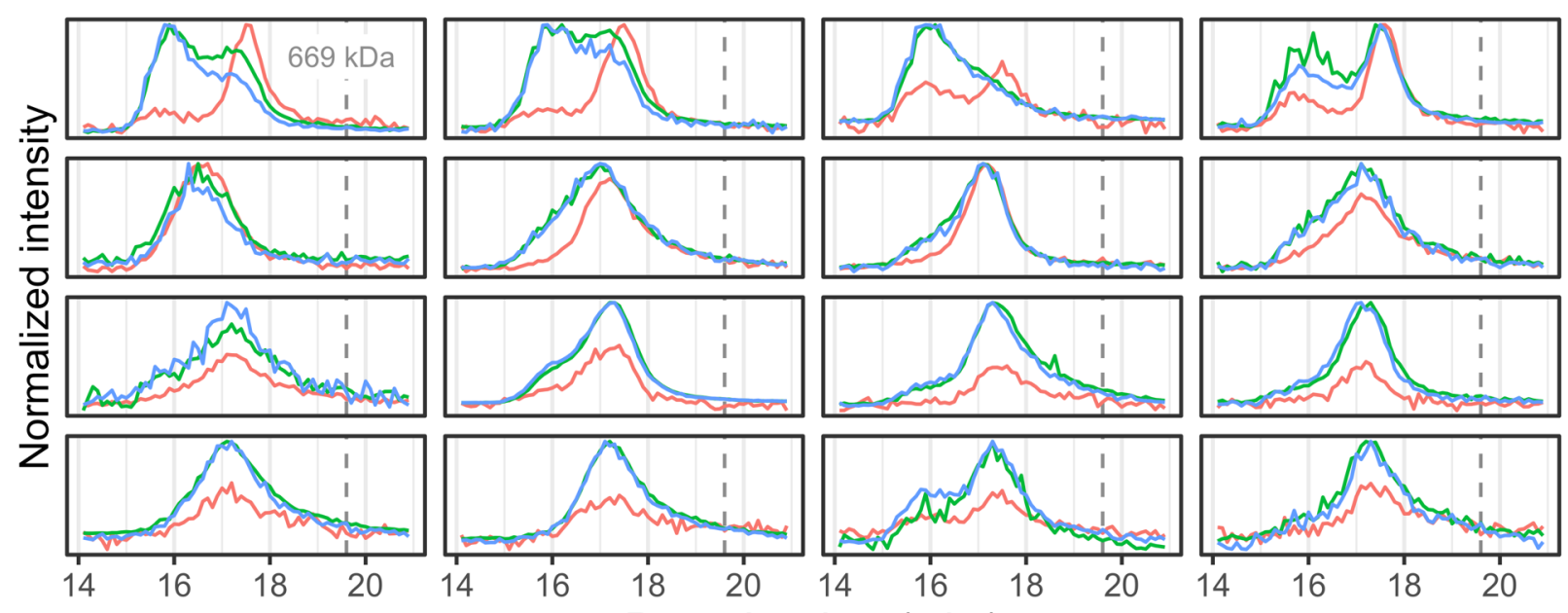

Retention time (min.)

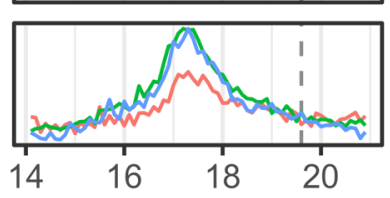

$-\mathrm{Al}-\mathrm{Fe}-\mathrm{Pb}$

Figure S1. As determined by size-exclusion chromatography, the relative size distributions of aluminum, iron, and lead were correlated at high apparent molecular weight $(n=16$ tap water samples). The colloidal fraction shown was sized nominally at $17-450 \mathrm{~nm}$. Intensities have been normalized for improved visualization, and the retention volume of thyroglobulin $(669 \mathrm{kDa}, 17$ $\mathrm{nm}$ hydrodynamic diameter) is indicated by the vertical dashed line. 

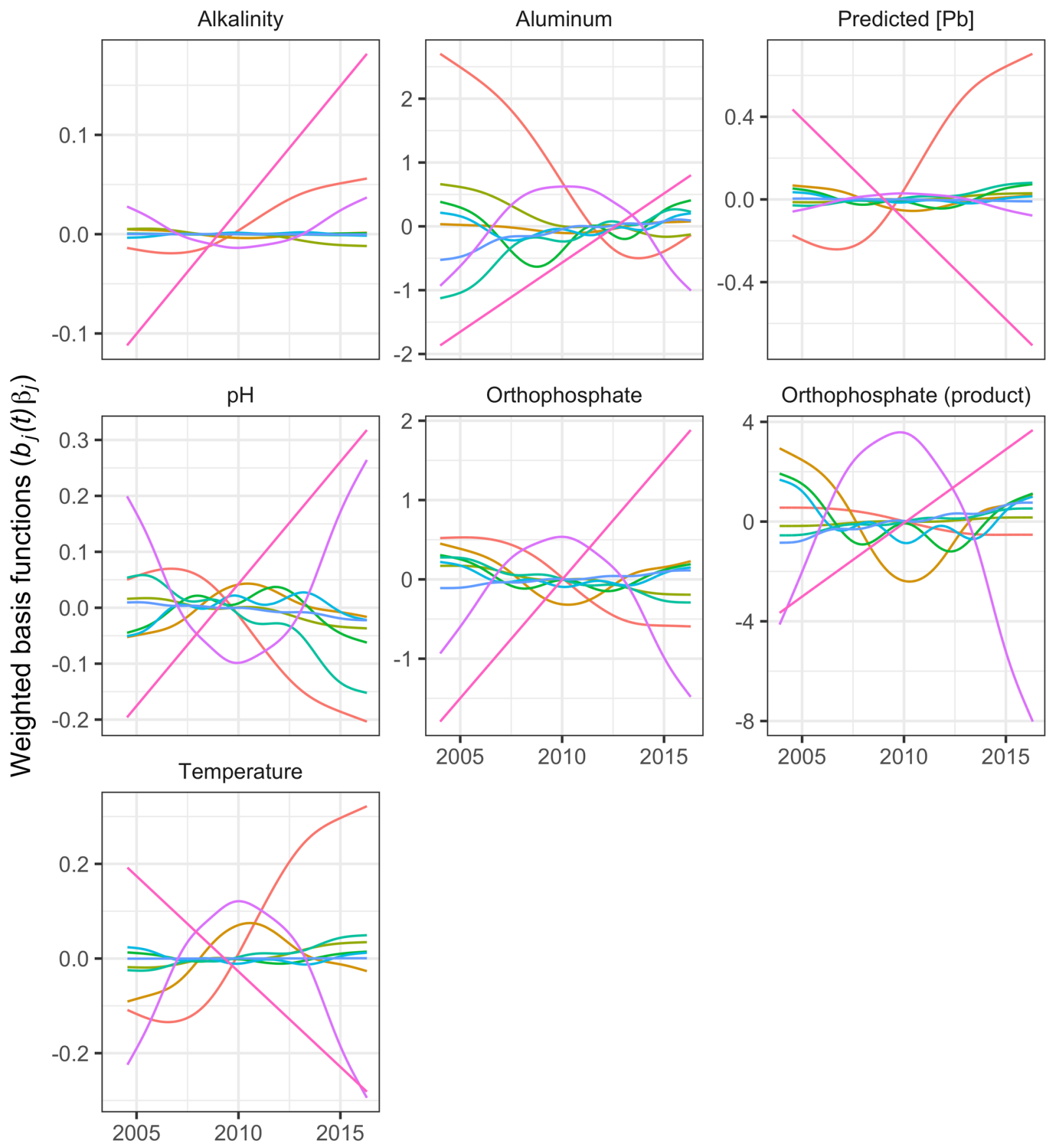

$$
\begin{aligned}
& -b_{1}(t) \beta_{1}-b_{3}(t) \beta_{3}-b_{5}(t) \beta_{5}-b_{7}(t) \beta_{7}-b_{9}(t) \beta_{9} \\
& -b_{2}(t) \beta_{2}-b_{4}(t) \beta_{4}-b_{6}(t) \beta_{6}-b_{8}(t) \beta_{8}
\end{aligned}
$$

Figure S2. Weighted basis functions comprising the long-term time series trends. 


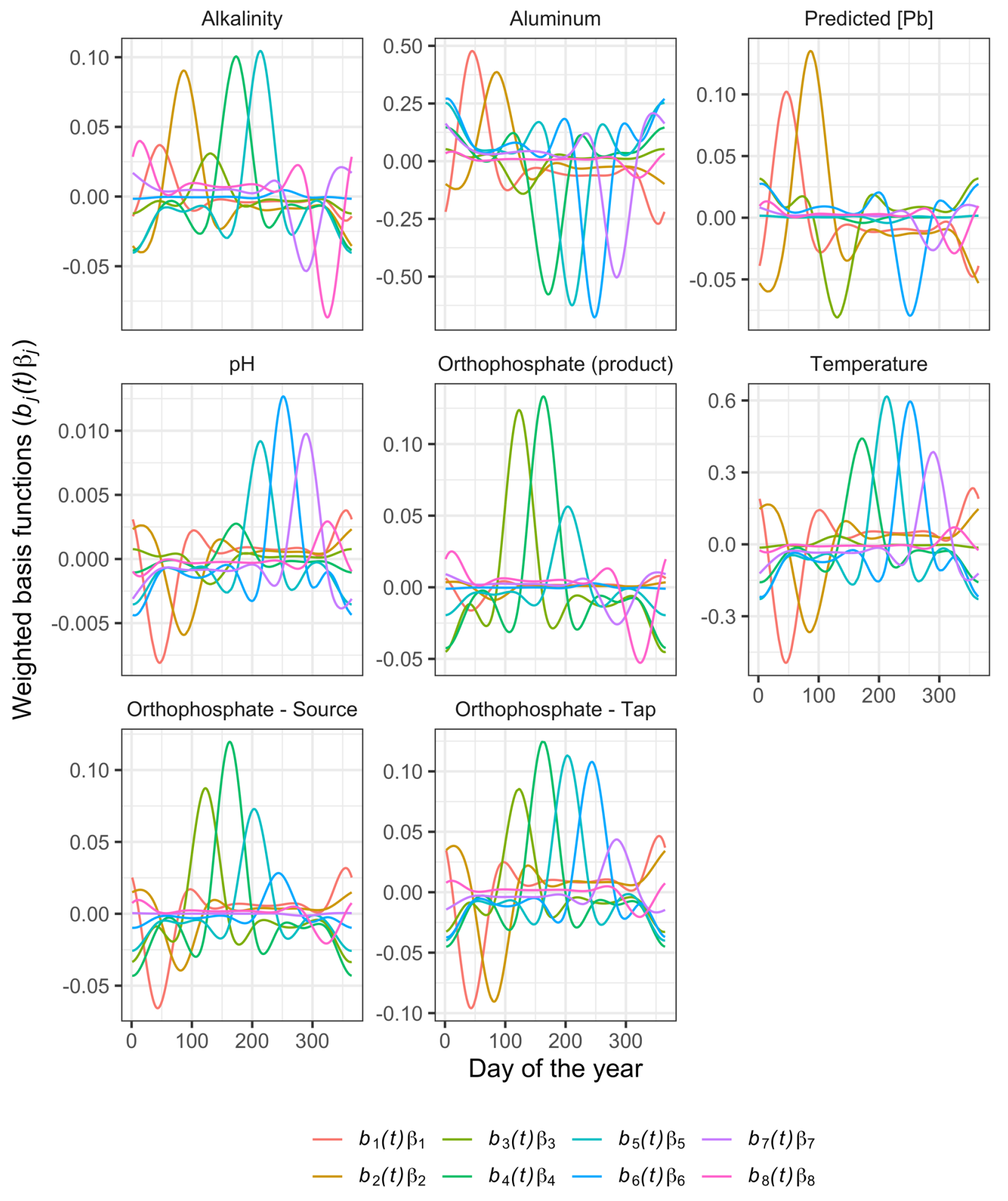

Figure S3. Weighted basis functions comprising the seasonal time series trends. 


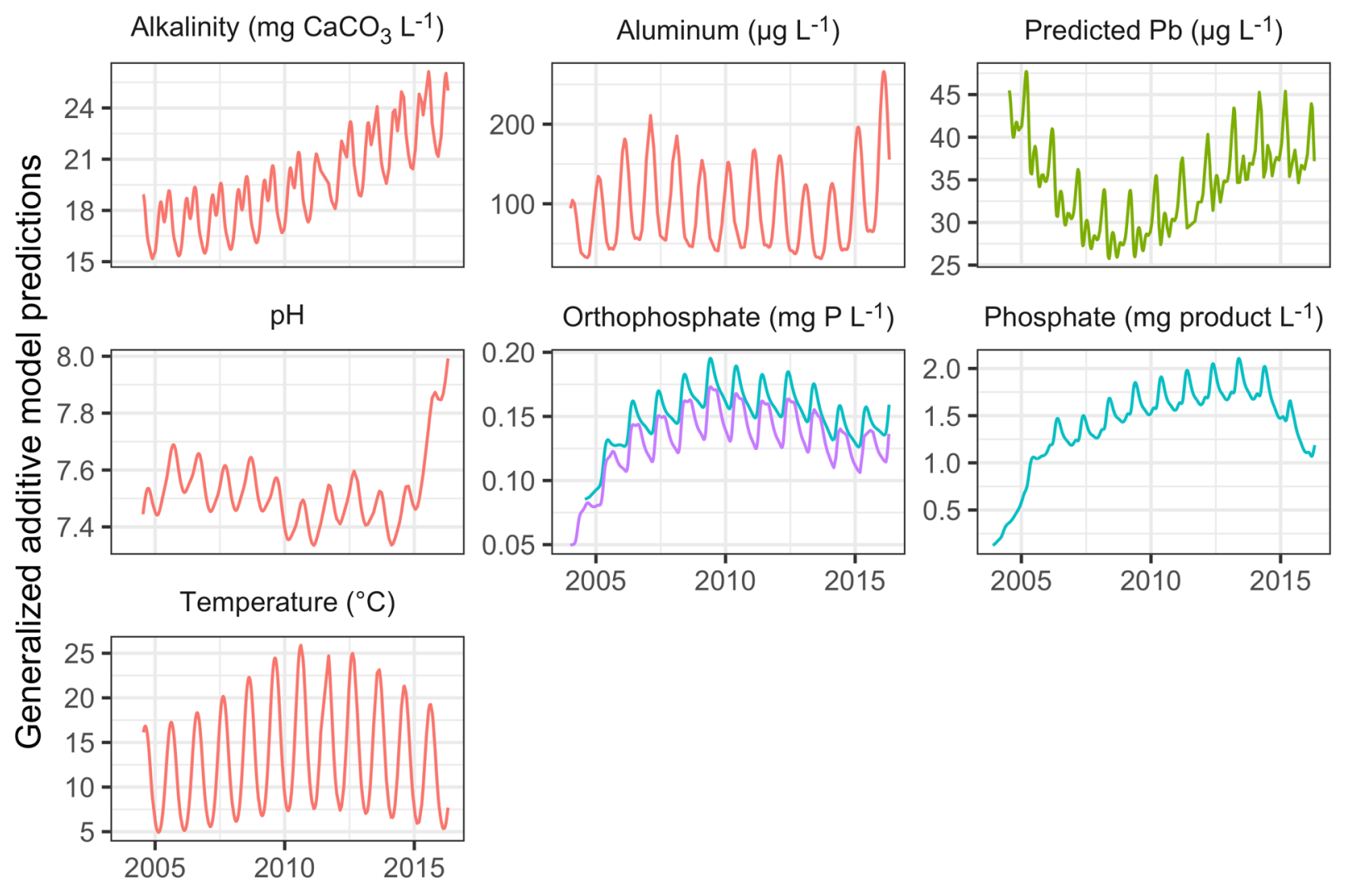

- Combined - Predicted - Source - Tap

Figure S4. Generalized additive model predictions for each water chemistry time series. 

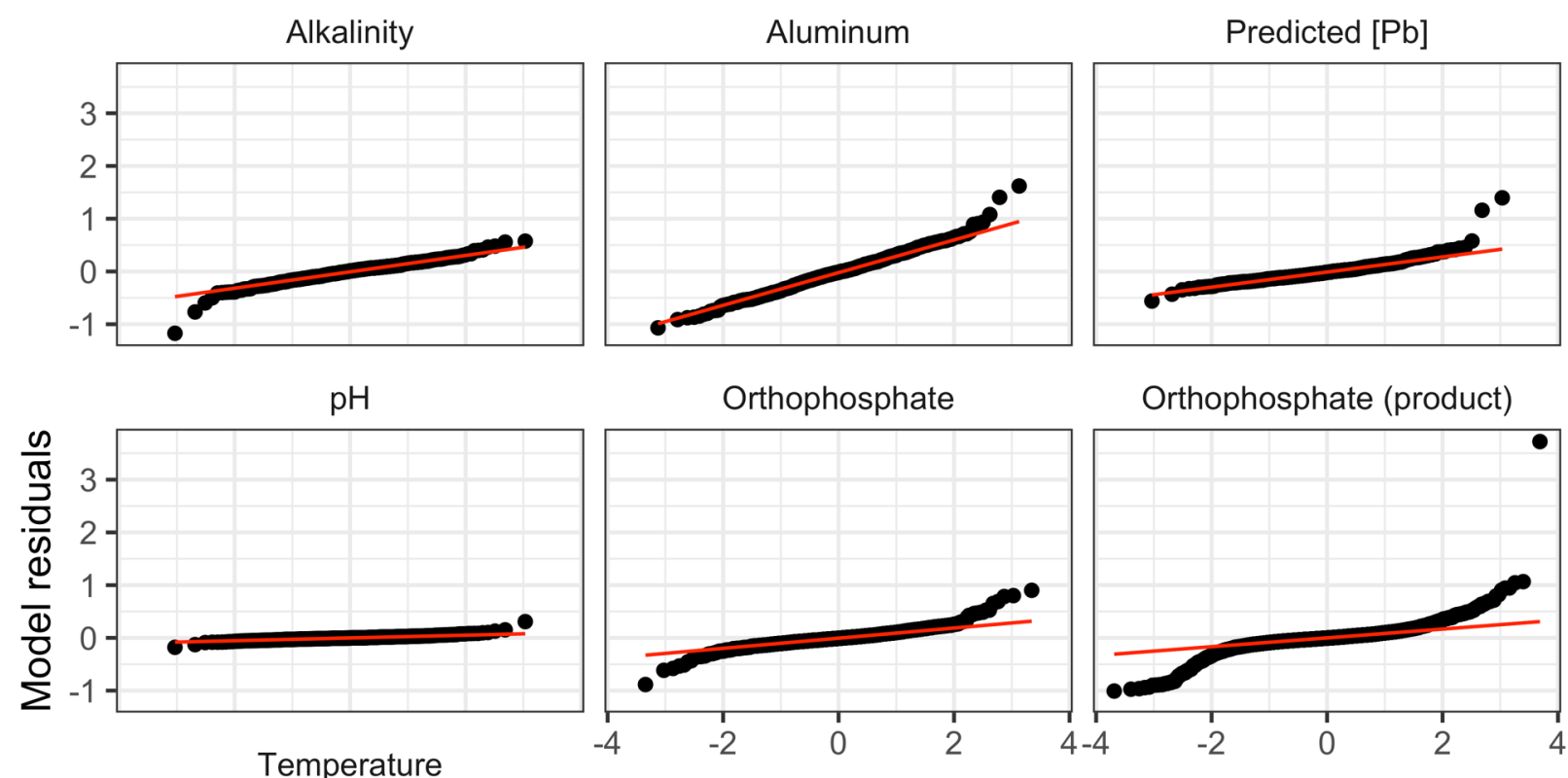

Orthophosphate (product)

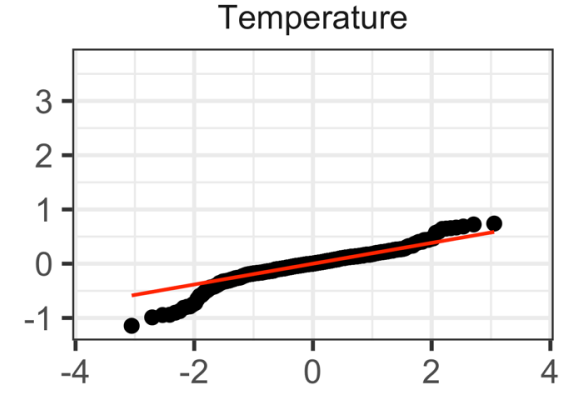

Theoretical normal quantiles

Figure S5. Model residuals plotted against the standard normal quantiles, by parameter. 

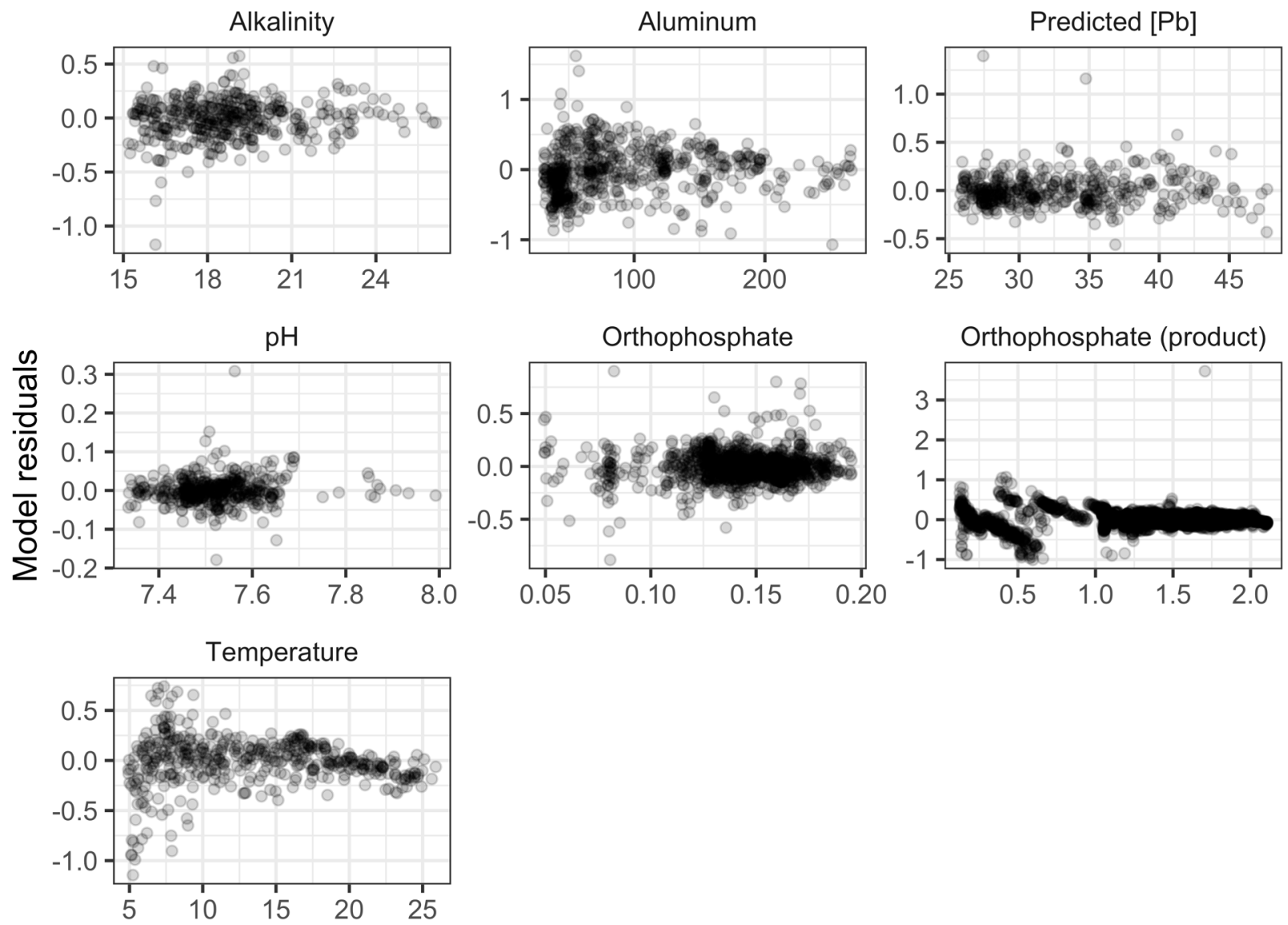

\section{Fitted values}

Figure S6. Model residuals plotted against the fitted values, by parameter. 

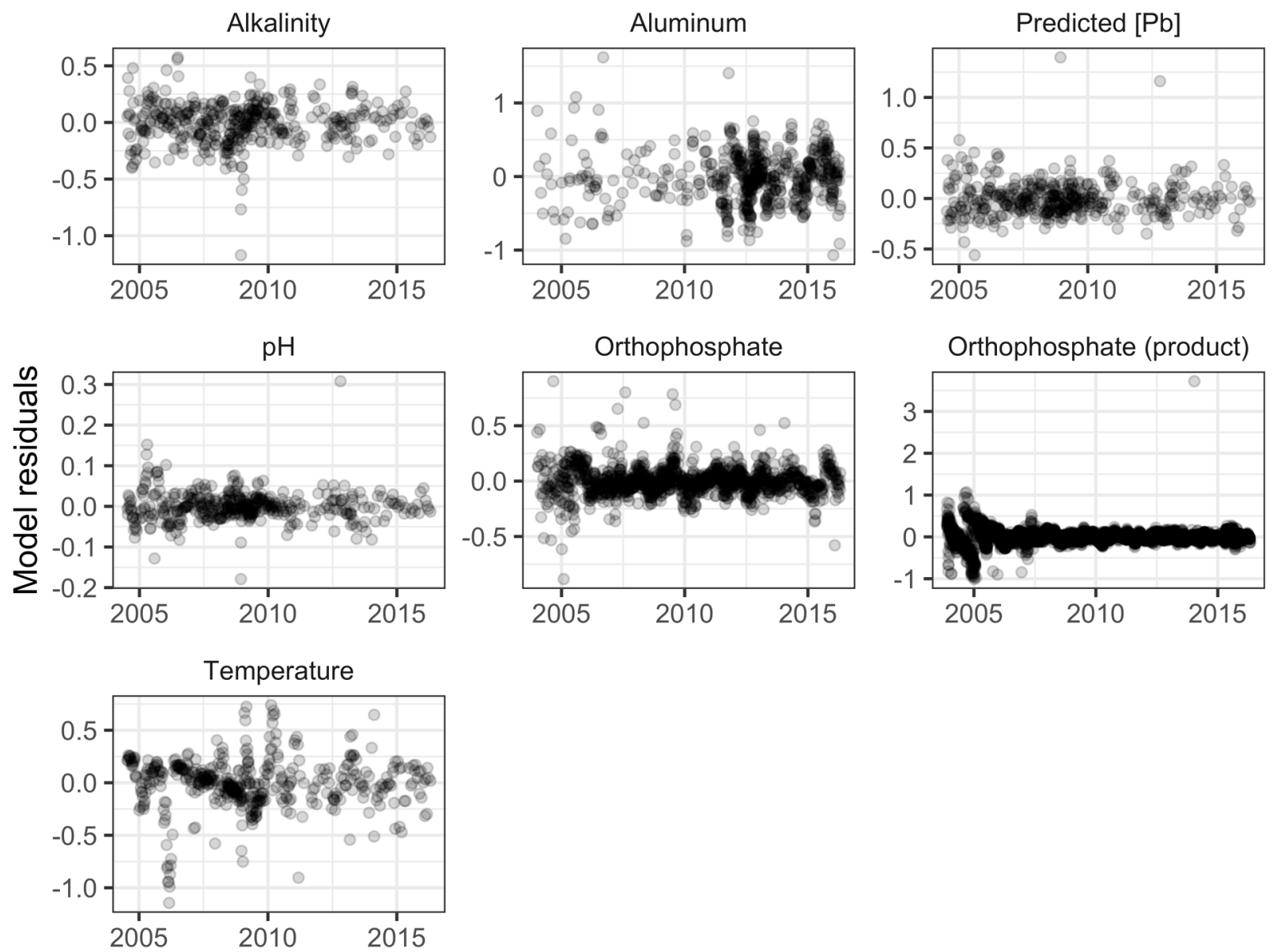

Figure S7. Model residuals over time, by parameter. 

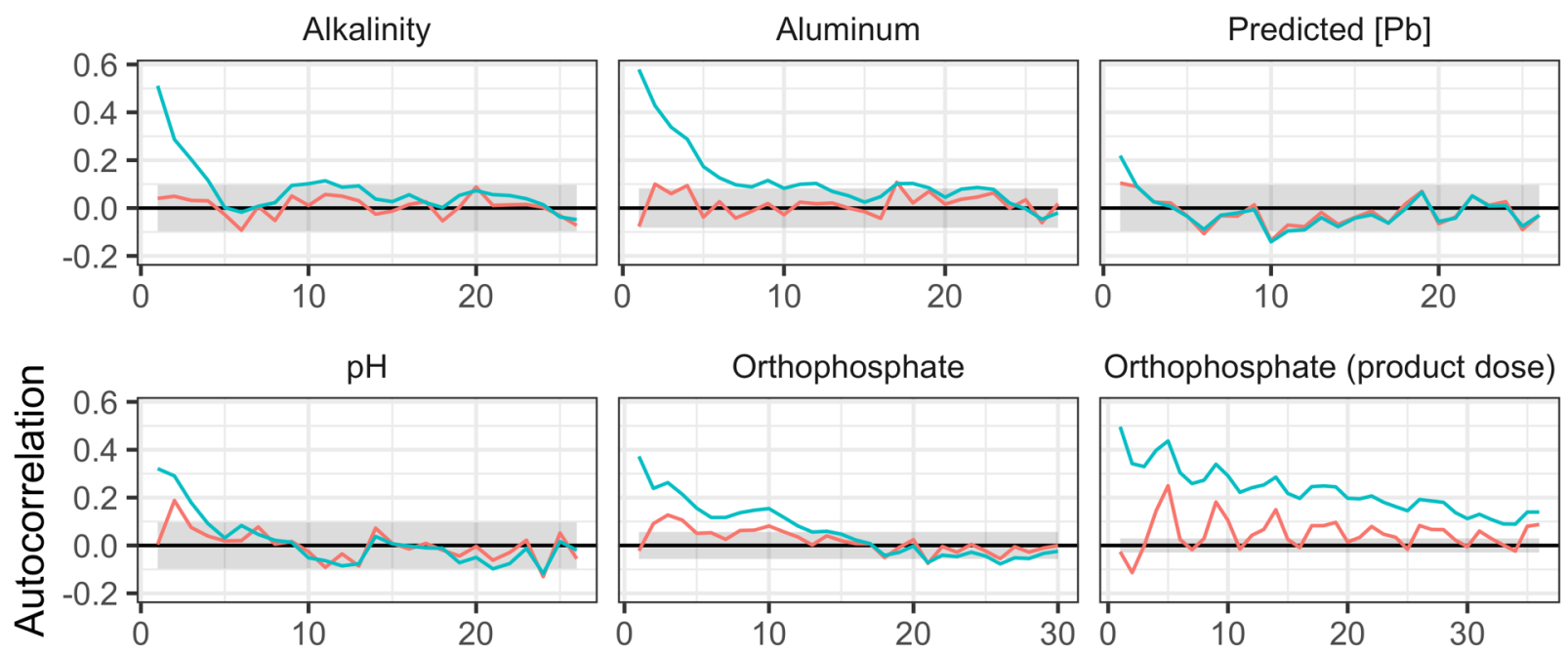

Orthophosphate (product dose)
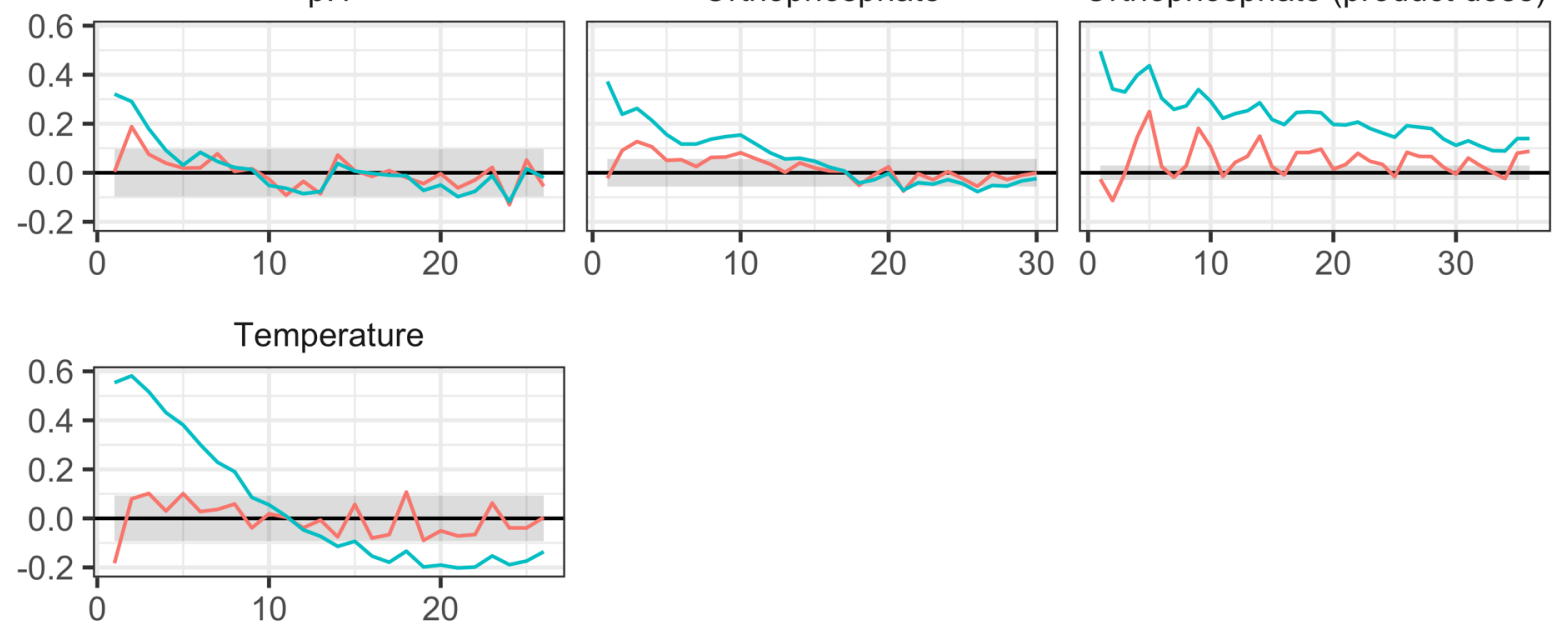

Time lag

Residual type — Normalized — Raw

Figure S8. Autocorrelation functions of the raw and normalized model residuals. Shaded grey bands denote the critical values $\pm 1.96 / \sqrt{n}$. Normalization here refers to raw residuals divided by their corresponding standard errors and pre-multiplied by the inverse square-root factor of the estimated error correlation matrix (i.e., the R function nlme: : residuals.lme()). 
a

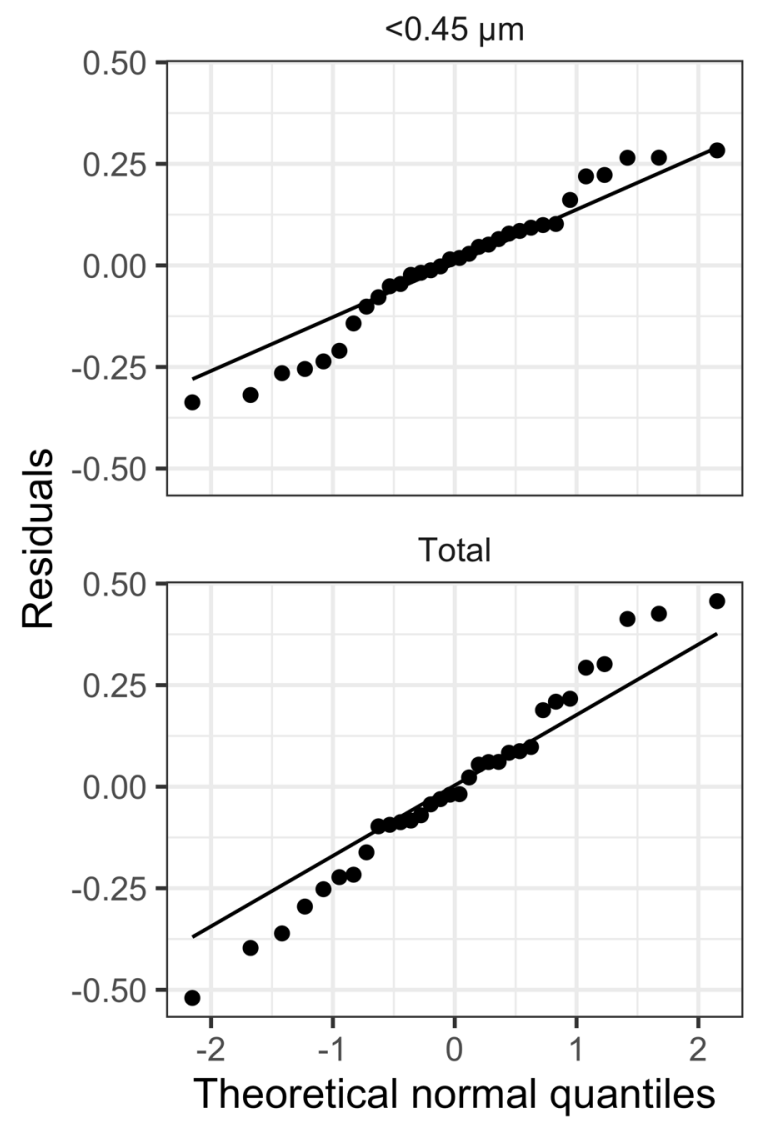

b

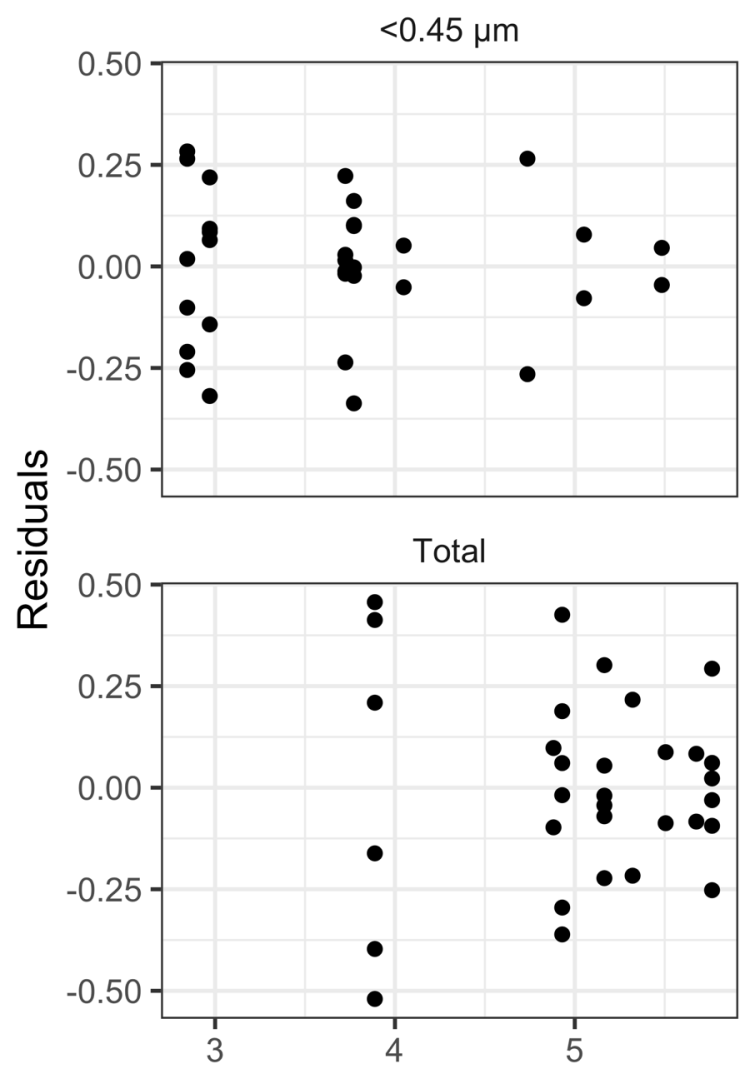

Fitted values

Figure S9. After a natural log transformation of the response variable, linear model residuals were (a) approximately Gaussian and (b) homoscedastic. 
a
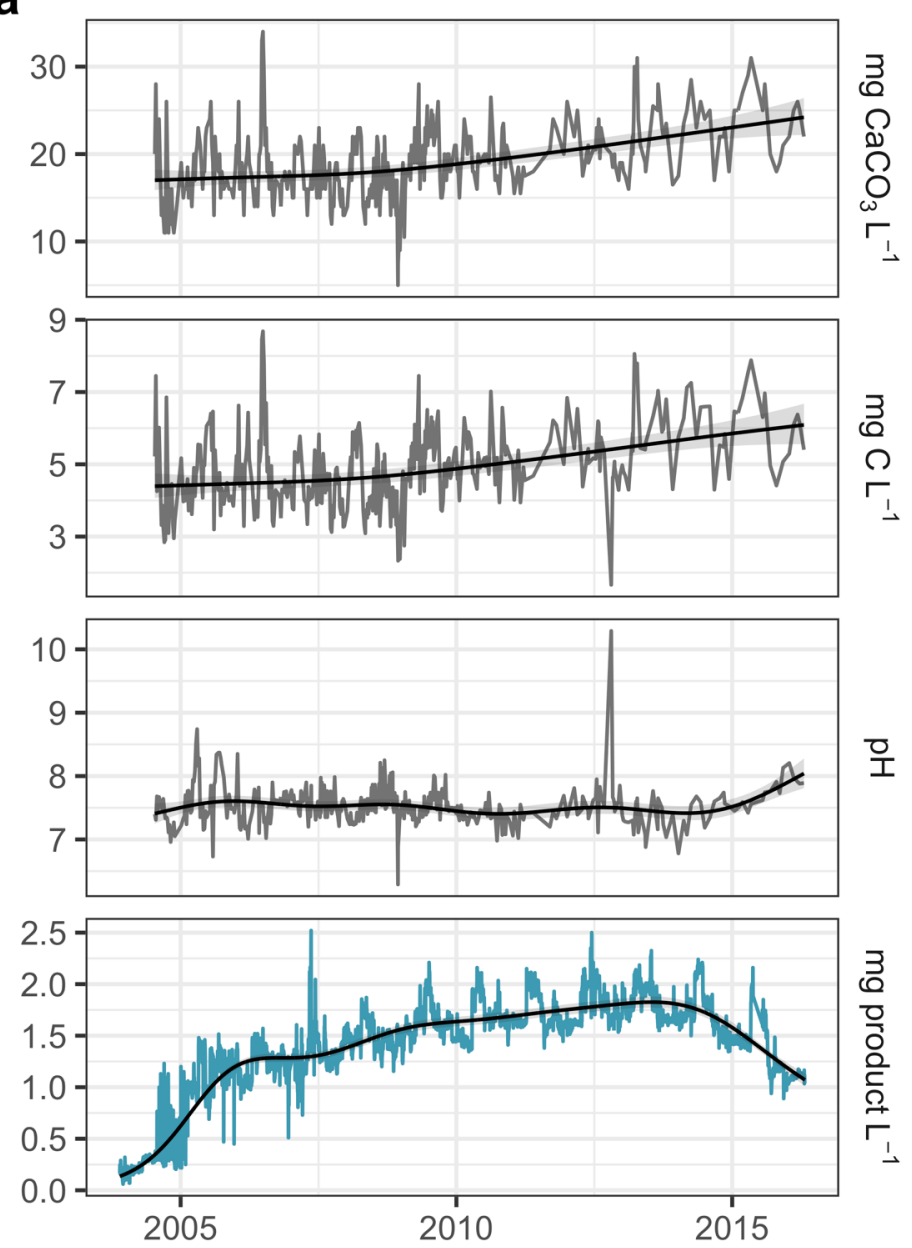

b
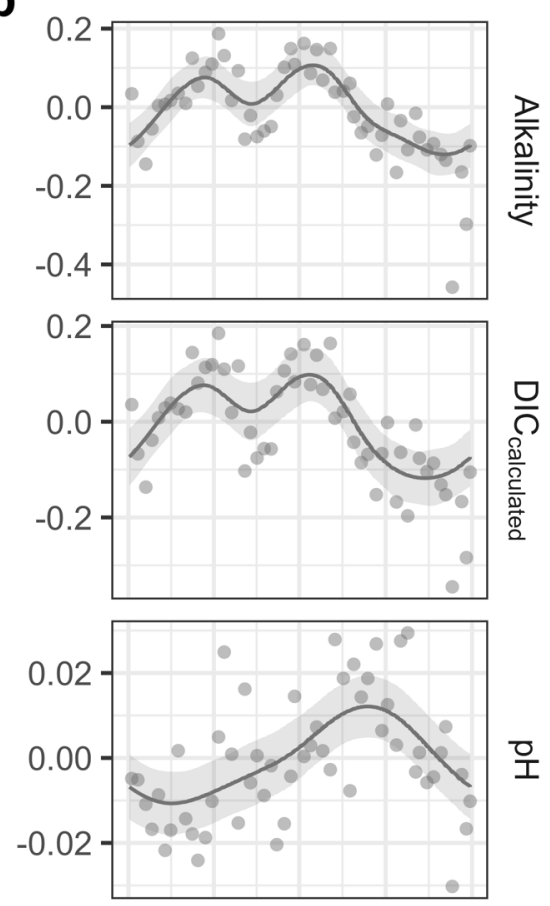

호

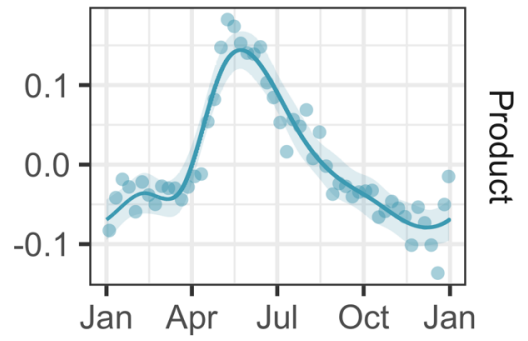

- Combined Source

Figure S10. (a) Mean alkalinity (as $\mathrm{CaCO}_{3}$ ), $\mathrm{pH}$, and orthophosphate product dose by date. Combined indicates that the series includes data collected at the treatment plant and in the distribution system, whereas source indicates that data were collected at the treatment plant only. The long-term smooth component of the additive fit to the data is superimposed. (b) The seasonal component of each additive model, along with the partial residuals representing the differences between the data and the non-seasonal components of the model, aggregated into weekly means. Shaded regions represent point-wise $95 \%$ confidence intervals on the fitted values. 


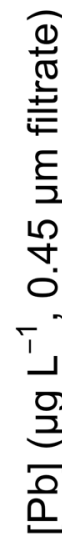

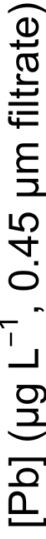

$\mathrm{Cu}$

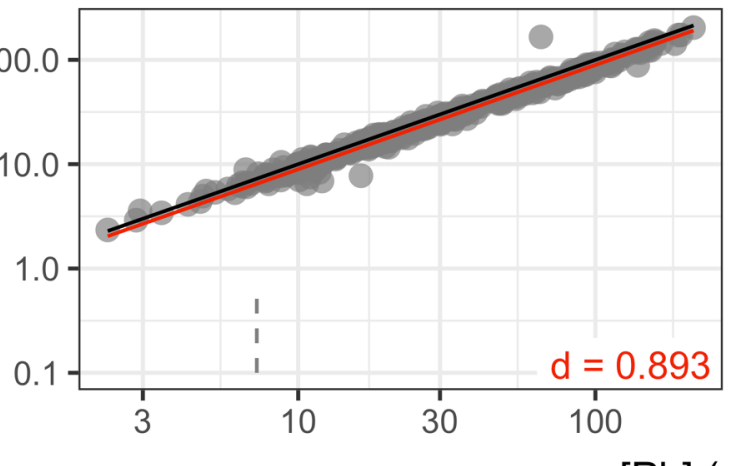

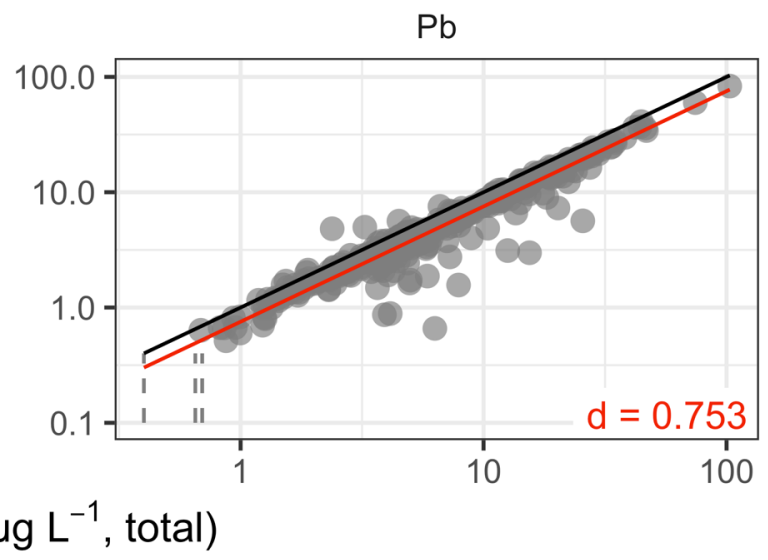

- Difference estimate $(y=d x)-y=x$

Figure S11. Lead and copper in paired filtered $(0.45 \mu \mathrm{m})$ and unfiltered aliquots representing 360 samples collected as profiles at residences with full or partial lead service lines. The difference estimate in each panel (red line) was estimated using the $R$ function NADA2: : cen_paired ( ) after a natural log transformation of both variables. Left-censored measurements are shown as dashed grey lines.

$$
[\mathrm{Al}]=500 \mu \mathrm{g} \mathrm{L}-1-[\mathrm{Al}]=20 \mu \mathrm{g} \mathrm{L}{ }^{-1} \quad 04^{\circ} \mathrm{C} \boldsymbol{\Delta} 21^{\circ} \mathrm{C}
$$
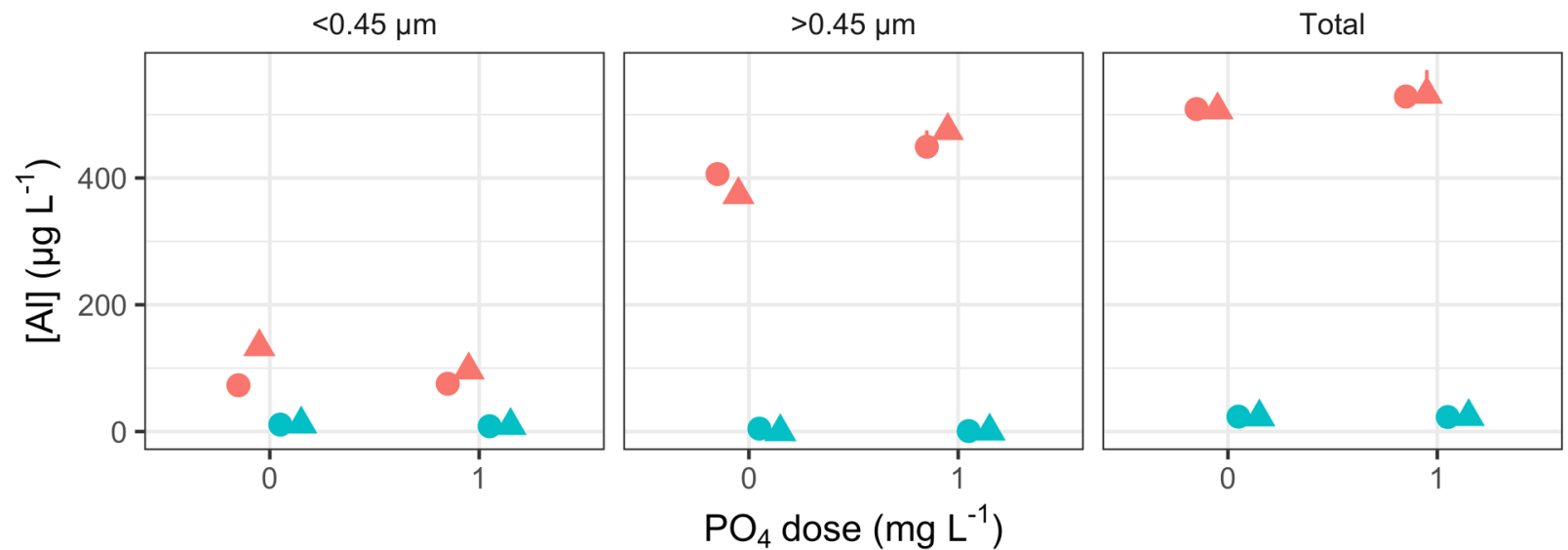

Figure S12. Median aluminum in static corrosion cells as a function of temperature, aluminum concentration, and orthophosphate dose. Error bars span the interquartile range. 
$0 \mathrm{mg} \mathrm{PO}_{4} \mathrm{~L}^{-1}$
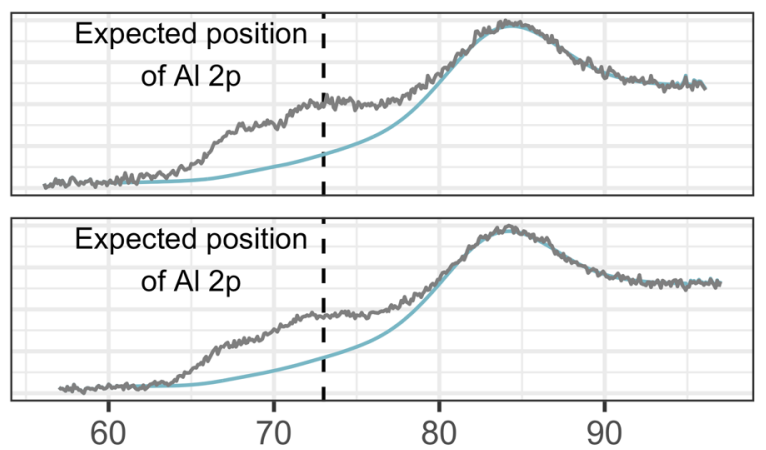

Binding energy (eV)

- $\mathrm{Pb} 5 \mathrm{p}_{3 / 2}-$ High-resolution scan

Figure S13. High-resolution XPS scans of lead coupons exposed to $0.5 \mathrm{mg} \mathrm{Al} \mathrm{L}^{-1}$, before and after removal of corrosion scale. The feature at $73 \mathrm{eV}$ was present in scans acquired before and after removal of the corrosion scale and was not attributable to aluminum. 


\section{Tables}

Table S1. Static corrosion cell experimental design. [Al] represents observations in 24-hour stagnant test water, while the other settings are nominal.

$\begin{array}{rrrr}{\left[\mathrm{PO}_{4}\right] \text { initial }} \\ \left(\mathrm{mg} \mathrm{L}^{-1}\right) & \text { Temperature (deg. C) } & {[\mathrm{Al}](\mu \mathrm{g} \mathrm{L}-1)} & \text { Replicates } \\ 0 & 4 & 20 & 2 \\ 0 & 4 & 500 & 2 \\ 0 & 21 & 20 & 2 \\ 0 & 21 & 500 & 2 \\ 1 & 4 & 20 & 6 \\ 1 & 4 & 500 & 6 \\ 1 & 21 & 20 & 6 \\ 1 & 21 & 500 & 6\end{array}$

Table S2. Chemical analysis of untreated water from the water supply plant (source: utility data).

$\begin{array}{ll}\text { Parameter } & \text { Untreated water } \\ \text { Alkalinity }\left(\mathrm{mg} \mathrm{CaCO}_{3} \mathrm{~L}^{-1}\right) & <5.0 \\ \text { Calcium }\left(\mathrm{mg} \mathrm{L}^{-1}\right) & 1 \\ \text { Chloride }\left(\mathrm{mg} \mathrm{L}^{-1}\right) & 6.4 \\ \text { True colour }\left(\mathrm{PtCo}^{-1}\right) & 17 \\ \text { Conductivity }\left(\mu \mathrm{C} \mathrm{cm}^{-1}\right) & 32 \\ \text { Hardness }\left(\mathrm{mg} \mathrm{CaCO}_{3} \mathrm{~L}^{-1}\right) & 3.9 \\ \text { Magnesium }\left(\mathrm{mg} \mathrm{L}^{-1}\right) & 0.39 \\ \mathrm{pH} & 6.1 \\ \text { Potassium }\left(\mathrm{mg} \mathrm{L}^{-1}\right) & 0.23 \\ \text { Sodium }\left(\mathrm{mg} \mathrm{L}^{-1}\right) & 4.3 \\ \text { Sulfate }\left(\mathrm{mg} \mathrm{L}^{-1}\right) & 3.2 \\ \text { Total Organic Carbon }\left(\mathrm{mg} \mathrm{C} \mathrm{L}^{-1}\right) & 3.8\end{array}$


Table S3. Standard XRD patterns and their PDF entry numbers.

$\begin{array}{ll}\text { Phase } & \text { PDF entry no. } \\ \text { Hydroxypyromorphite } & \text { 00-086-0236 } \\ \text { Hydrocerussite } & 96-210-8232 \\ \text { Massicot } & 96-900-7711 \\ \text { Lead } & 96-153-1229\end{array}$

Table S4. Summary of thermodynamic data used in equilibrium solubility modeling (LEADSOL values).

\begin{tabular}{|c|c|c|}
\hline Phase & Equation & $\log K$ \\
\hline - & $\mathrm{Pb}^{+2}+\mathrm{H}_{2} \mathrm{O}=\mathrm{PbOH}^{+}+\mathrm{H}^{+}$ & -7.22 \\
\hline- & $\mathrm{Pb}^{+2}+2 \mathrm{H}_{2} \mathrm{O}=\mathrm{Pb}(\mathrm{OH})_{2}+2 \mathrm{H}^{+}$ & -16.91 \\
\hline - & $\mathrm{Pb}^{+2}+3 \mathrm{H}_{2} \mathrm{O}=\mathrm{Pb}(\mathrm{OH})_{3}^{-}+3 \mathrm{H}^{+}$ & -28.08 \\
\hline - & $\mathrm{Pb}^{+2}+4 \mathrm{H}_{2} \mathrm{O}=\mathrm{Pb}(\mathrm{OH})_{4}^{-2}+4 \mathrm{H}^{+}$ & -39.72 \\
\hline - & $2 \mathrm{~Pb}^{+2}+\mathrm{H}_{2} \mathrm{O}=\mathrm{Pb}_{2} \mathrm{OH}^{+3}+\mathrm{H}^{+}$ & -6.36 \\
\hline - & $3 \mathrm{~Pb}^{+2}+4 \mathrm{H}_{2} \mathrm{O}=\mathrm{Pb}_{3}(\mathrm{OH})_{4}+2+4 \mathrm{H}^{+}$ & -23.86 \\
\hline- & $4 \mathrm{~Pb}^{+2}+4 \mathrm{H}_{2} \mathrm{O}=\mathrm{Pb}_{4}(\mathrm{OH})_{4}+4+4 \mathrm{H}^{+}$ & -20.88 \\
\hline- & $6 \mathrm{~Pb}^{+2}+8 \mathrm{H}_{2} \mathrm{O}=\mathrm{Pb}_{6}(\mathrm{OH})_{8}+4+8 \mathrm{H}^{+}$ & -43.62 \\
\hline- & $\mathrm{Pb}^{+2}+\mathrm{CO}_{3}^{-2}=\mathrm{PbCO}_{3}$ & 7.10 \\
\hline- & $\mathrm{Pb}^{+2}+2 \mathrm{CO}_{3}^{-2}=\mathrm{Pb}\left(\mathrm{CO}_{3}\right)_{2^{-2}}$ & 10.33 \\
\hline- & $\mathrm{Pb}^{+2}+\mathrm{CO}_{3}^{-2}+\mathrm{H}^{+}=\mathrm{PbHCO}_{3}^{+}$ & 12.59 \\
\hline- & $\mathrm{Pb}^{+2}+\mathrm{PO}_{4}^{-3}+\mathrm{H}^{+}=\mathrm{PbHPO}_{4}$ & 15.41 \\
\hline- & $\mathrm{Pb}^{+2}+\mathrm{PO}_{4}^{-3}+2 \mathrm{H}^{+}=\mathrm{PbH}_{2} \mathrm{PO}_{4}^{+}$ & 21.05 \\
\hline- & $\mathrm{Pb}^{+2}+\mathrm{SO}_{4}^{-2}=\mathrm{PbSO}_{4}$ & 2.73 \\
\hline- & $\mathrm{Pb}^{+2}+2 \mathrm{SO}_{4}^{-2}=\mathrm{Pb}\left(\mathrm{SO}_{4}\right)_{2}^{-2}$ & 3.50 \\
\hline- & $\mathrm{Pb}^{+2}+\mathrm{Cl}^{-}=\mathrm{PbCl}^{+}$ & 1.59 \\
\hline - & $\mathrm{Pb}^{+2}+2 \mathrm{Cl}^{-}=\mathrm{PbCl}_{2}$ & 1.80 \\
\hline- & $\mathrm{Pb}^{+2}+3 \mathrm{Cl}^{-}=\mathrm{PbCl}_{3}^{-}$ & 1.71 \\
\hline - & $\mathrm{Pb}^{2}+4 \mathrm{Cl}^{-}=\mathrm{PbCl}_{4}^{-2}$ & 1.43 \\
\hline Cerussite & $\mathrm{PbCO}_{3}=\mathrm{Pb}^{+2}+\mathrm{CO}_{3}^{-2}$ & -13.11 \\
\hline Hydrocerussite & $\mathrm{Pb}(\mathrm{OH})_{2}: 2 \mathrm{PbCO}_{3}+2 \mathrm{H}^{+}=3 \mathrm{~Pb}^{+2}+2 \mathrm{CO}_{3}-2+2 \mathrm{H}_{2} \mathrm{O}$ & -18.00 \\
\hline Hydroxylpyromorphite & $\mathrm{Pb}_{5}\left(\mathrm{PO}_{4}\right)_{3} \mathrm{OH}+\mathrm{H}^{+}=5 \mathrm{~Pb}^{+2}+3 \mathrm{PO}_{4}^{-3}+\mathrm{H}_{2} \mathrm{O}$ & -62.83 \\
\hline
\end{tabular}


Table S5. Terms in the generalized additive models fitted to water chemistry time series. $f$ (day) is a function of the day of the year and $f$ (date) is a function of the date.

\begin{tabular}{|c|c|c|c|c|}
\hline Parameter & Term & Estimate & $p$-value & Adjusted $\mathrm{R}^{2}$ \\
\hline Alkalinity $\left(\mathrm{mg} \mathrm{CaCO}_{3} \mathrm{~L}^{-1}\right)$ & $f$ (date) & . & $<<0.001$ & 0.33 \\
\hline . & $f$ (day) & . & $<<0.001$ & . \\
\hline . & Intercept $\left(\beta_{0}\right)$ & 19.00 & $<<0.001$ & . \\
\hline . & $\phi$ & 0.86 & . & . \\
\hline Aluminum $\left(\mu \mathrm{g} \mathrm{L}^{-1}\right)$ & $f$ (date) & . & $<<0.001$ & 0.76 \\
\hline . & $f$ (day) & . & $<<0.001$ & . \\
\hline . & Intercept $\left(\beta_{0}\right)$ & 78.00 & $<<0.001$ & . \\
\hline . & $\phi$ & 0.83 & . & . \\
\hline Predicted [Pb] $\left(\mu \mathrm{g} \mathrm{L}^{-1}\right)$ & $f$ (date) & . & $<<0.001$ & 0.44 \\
\hline . & $f$ (day) & . & $<<0.001$ & . \\
\hline . & Intercept $\left(\beta_{0}\right)$ & 32.00 & $<<0.001$ & . \\
\hline . & $\phi$ & 0.51 & . & . \\
\hline $\mathrm{pH}$ & $f$ (date) & . & $<<0.001$ & 0.13 \\
\hline . & $f$ (day) & . & $<<0.001$ & . \\
\hline . & Intercept $\left(\beta_{0}\right)$ & 7.50 & $<<0.001$ & . \\
\hline . & $\phi$ & 0.79 & . & . \\
\hline Orthophosphate (mg P L-1) & $f($ date $)$ & . & $<<0.001$ & 0.71 \\
\hline . & $f(\text { day })_{\text {source }}$ & . & $<<0.001$ & . \\
\hline . & $f(\text { day })_{\text {tap }}$ & . & $<<0.001$ & . \\
\hline . & Intercept $\left(\beta_{0}\right)$ & 0.15 & $<<0.001$ & . \\
\hline . & $\operatorname{Tap}\left(\beta_{1}\right)$ & -11.00 & $<<0.001$ & . \\
\hline . & $\phi$ & 0.83 & . & . \\
\hline Orthophosphate (mg product $L^{-1}$ ) & $f($ date $)$ & . & $<<0.001$ & 0.91 \\
\hline . & $f$ (day) & . & $<<0.001$ & . \\
\hline . & Intercept $\left(\beta_{0}\right)$ & 1.30 & $<<0.001$ & . \\
\hline . & $\phi_{1}$ & 0.44 & . & . \\
\hline . & $\phi_{2}$ & 0.13 & . & . \\
\hline Temperature $\left({ }^{\circ} \mathrm{C}\right)$ & $f($ date $)$ & . & $<<0.001$ & 0.78 \\
\hline . & $f$ (day) & . & $<<0.001$ & . \\
\hline . & Intercept $\left(\beta_{0}\right)$ & 12.00 & $<<0.001$ & . \\
\hline . & $\phi_{1}$ & 0.11 & . & . \\
\hline . & $\phi_{2}$ & 0.82 & . & . \\
\hline
\end{tabular}




\section{$\mathbf{R}$ code}

\section{Supplementary text 1}

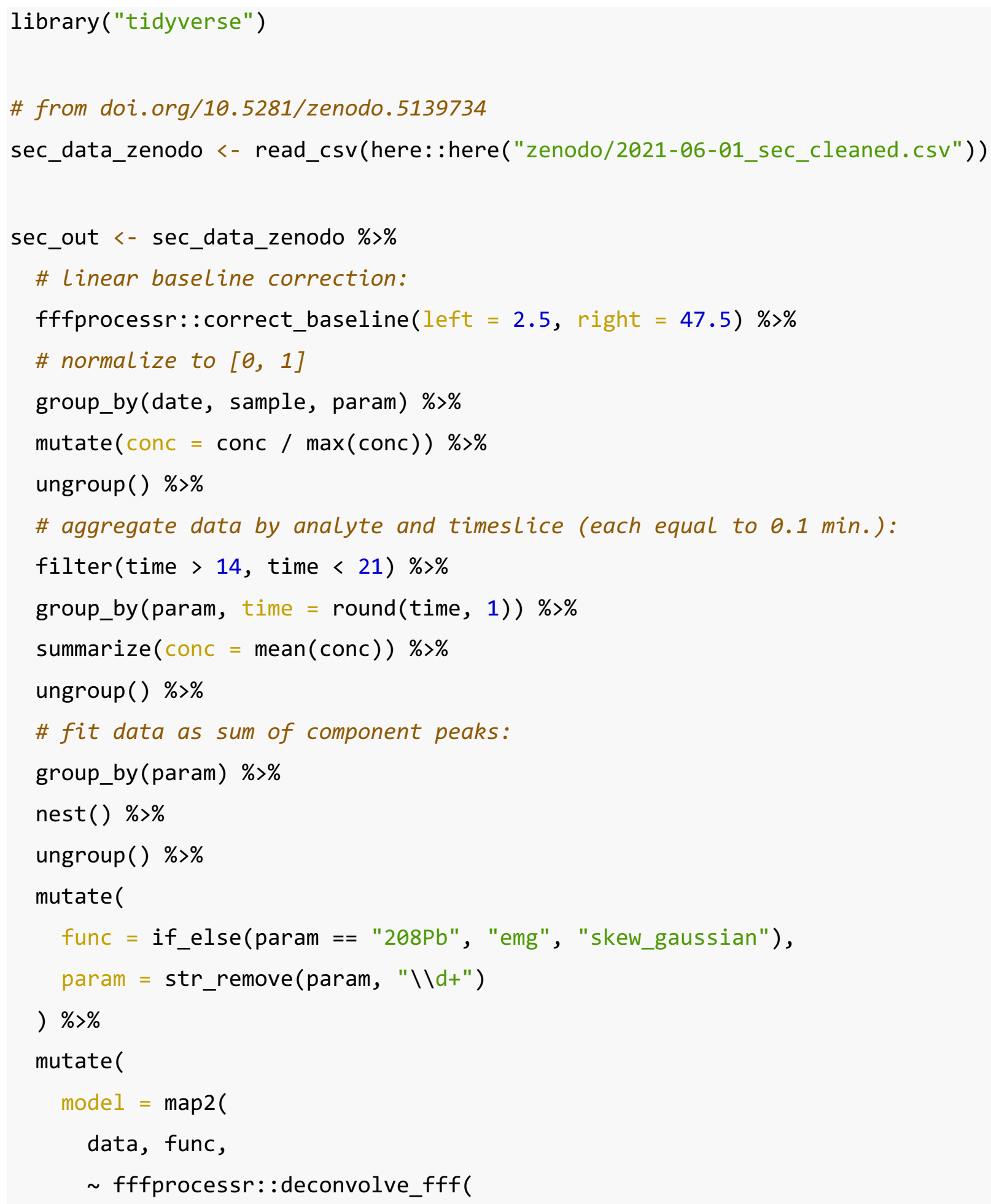




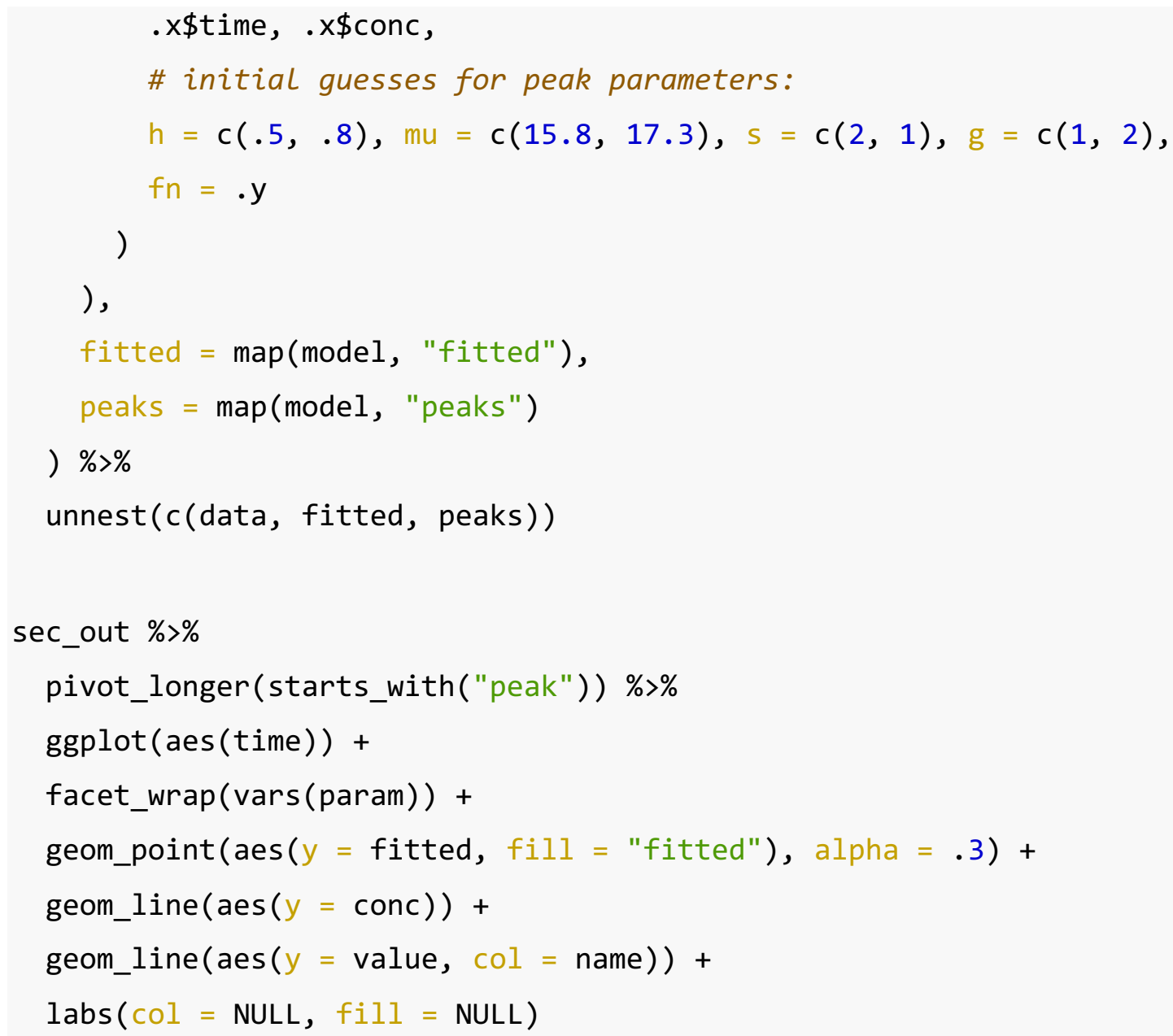

\section{Supplementary text 2}

library("tidyverse")

\# from doi.org/10.5281/zenodo.5139734

mthesis <- read_csv(here: :here("zenodo/2021-06-

01_mcilwain_thesis_cleaned.csv"))

mthesis_out <- mthesis \%>\%

mutate $($ param $=$ str_remove $($ param, $" \backslash \backslash . ")) \%>\%$

pivot_wider(

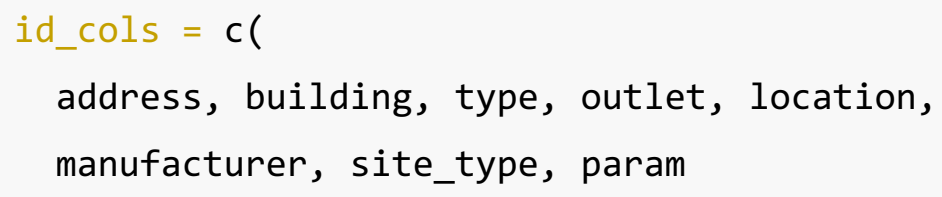




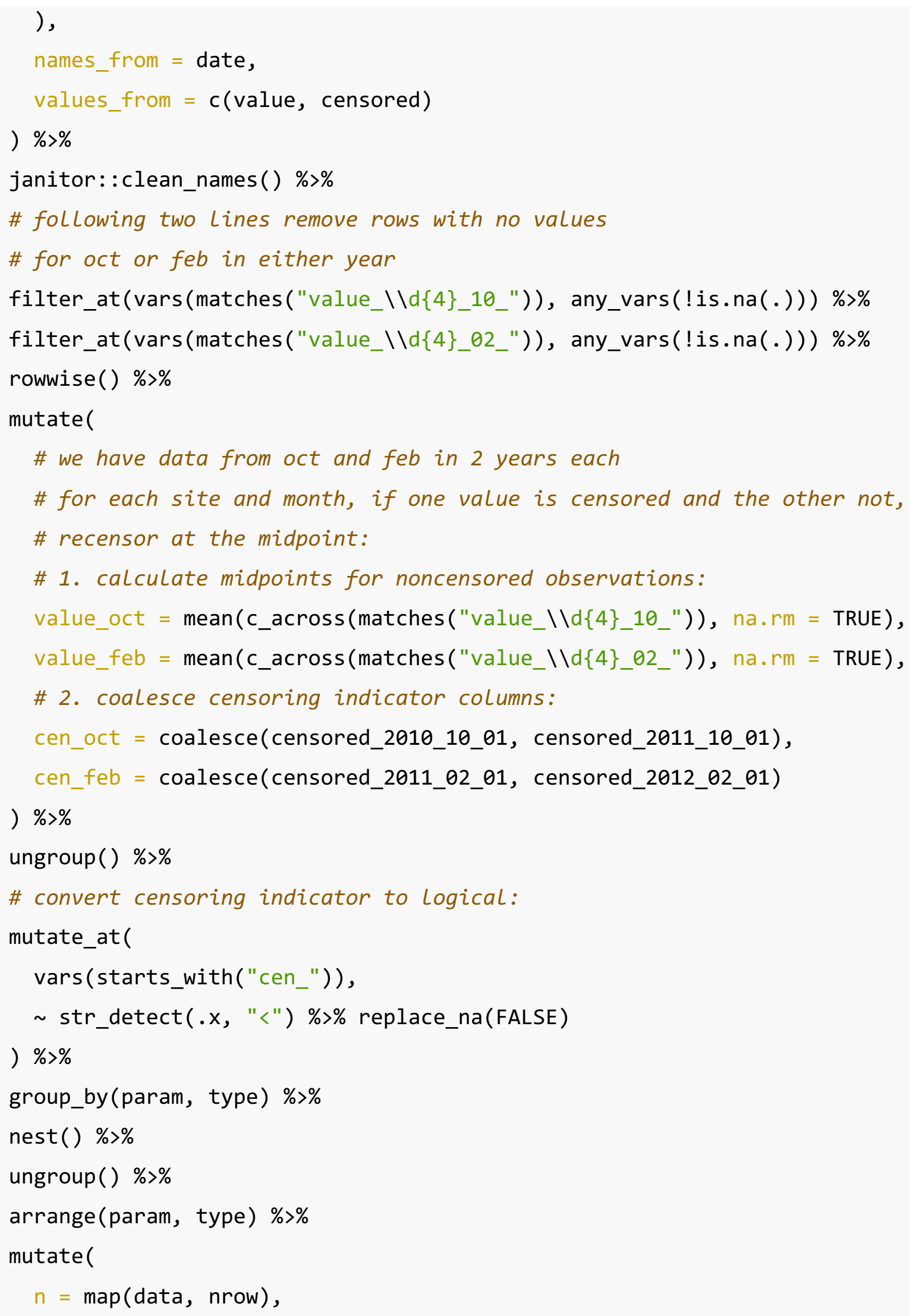




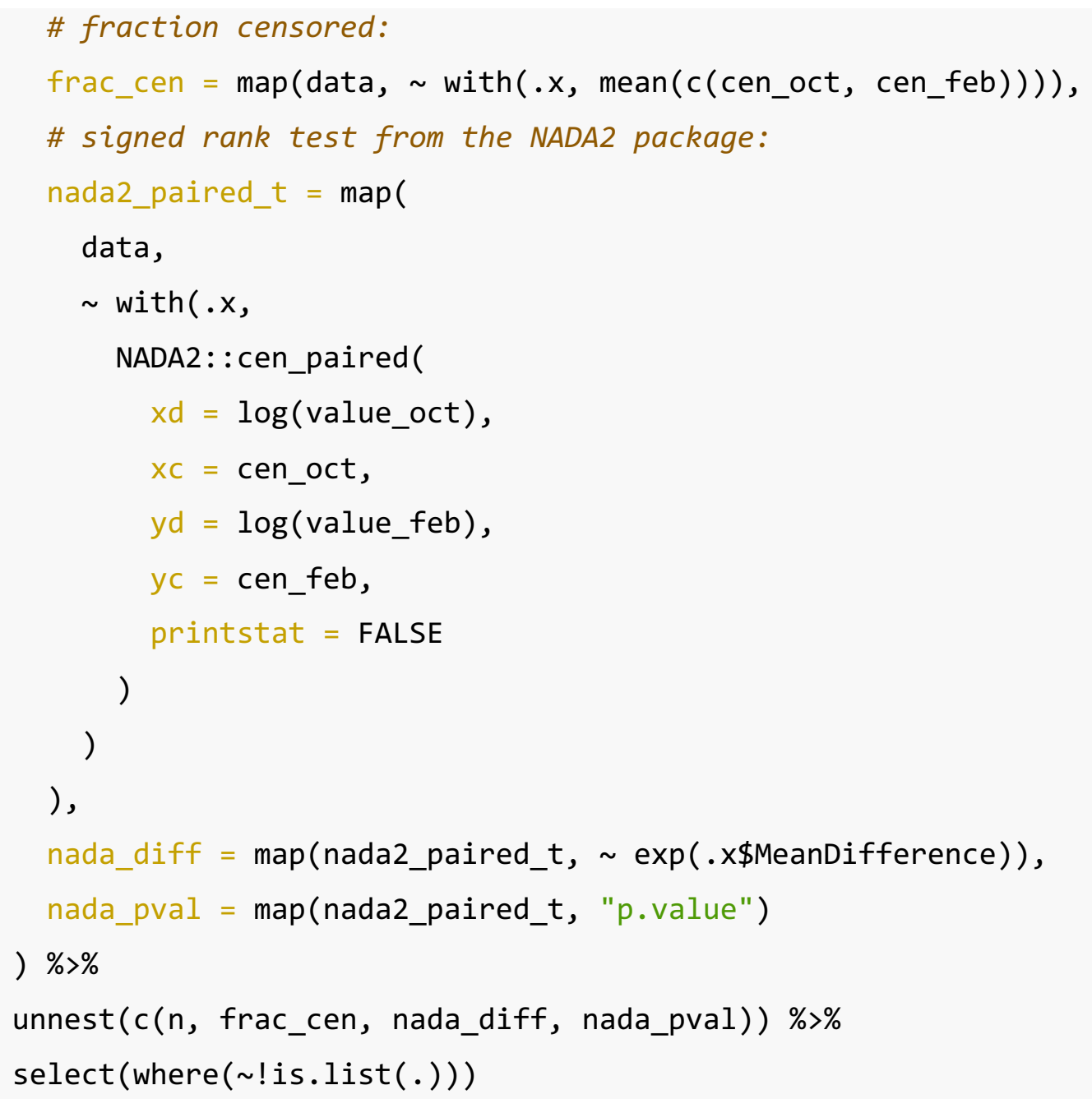

\section{Supplementary text 3}

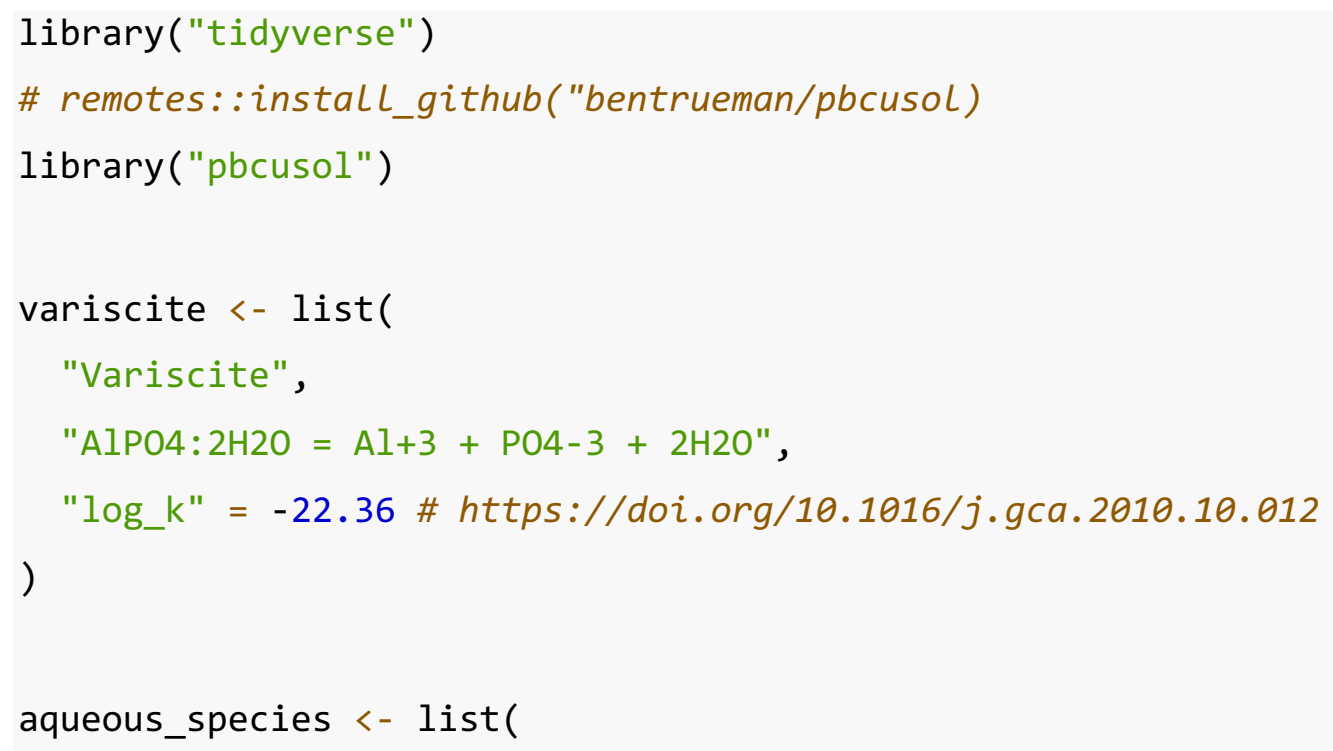




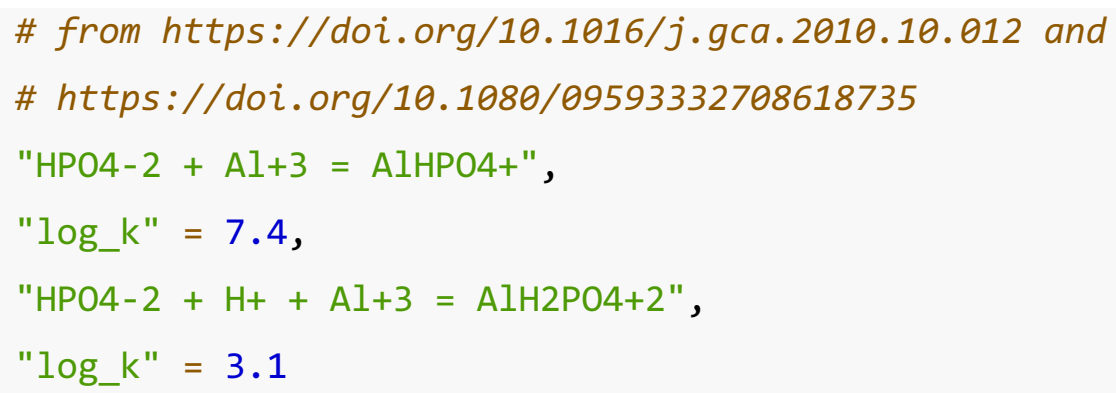




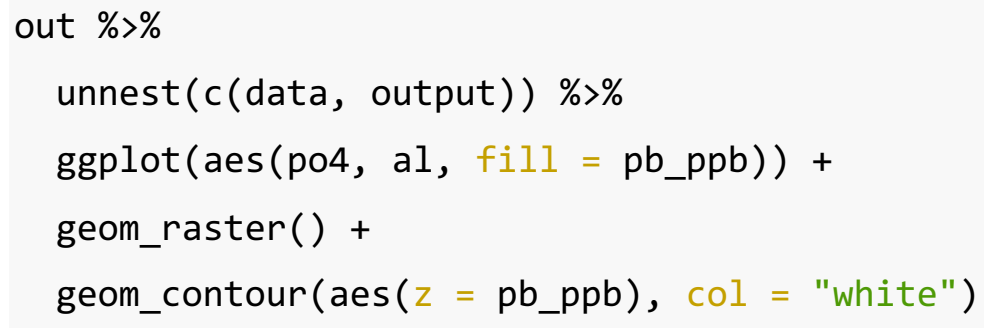

\section{Supplementary text 4}

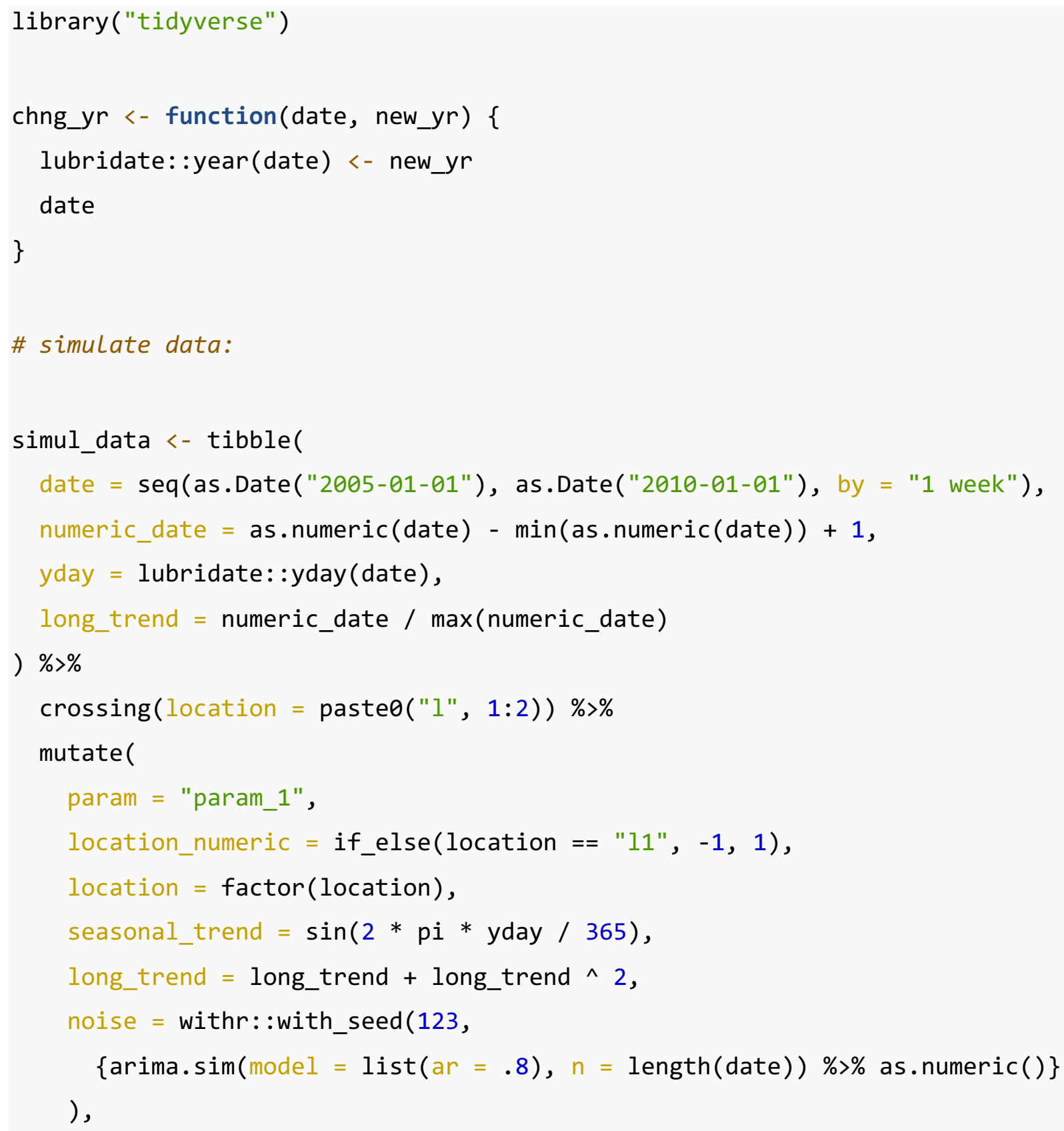




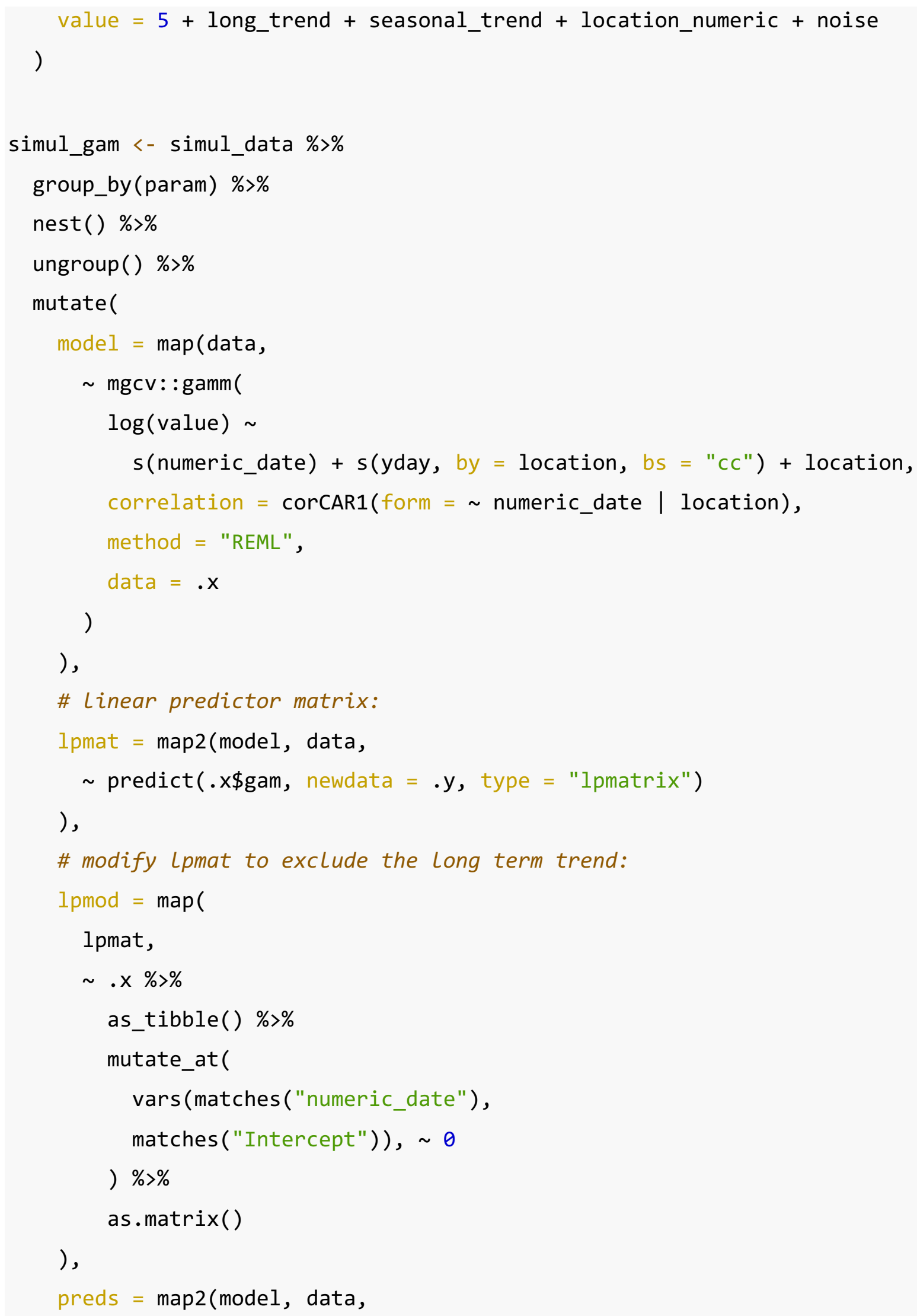




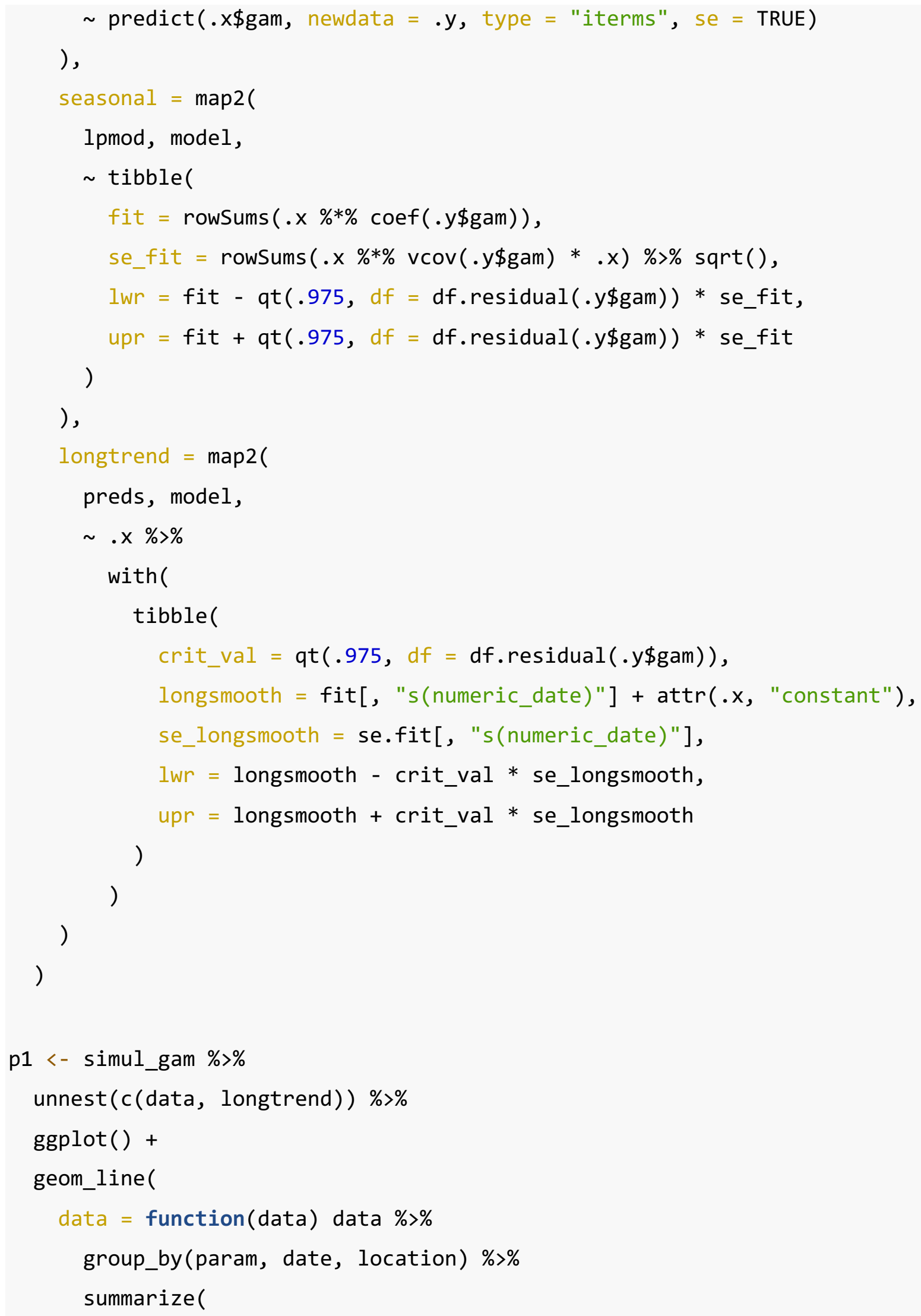




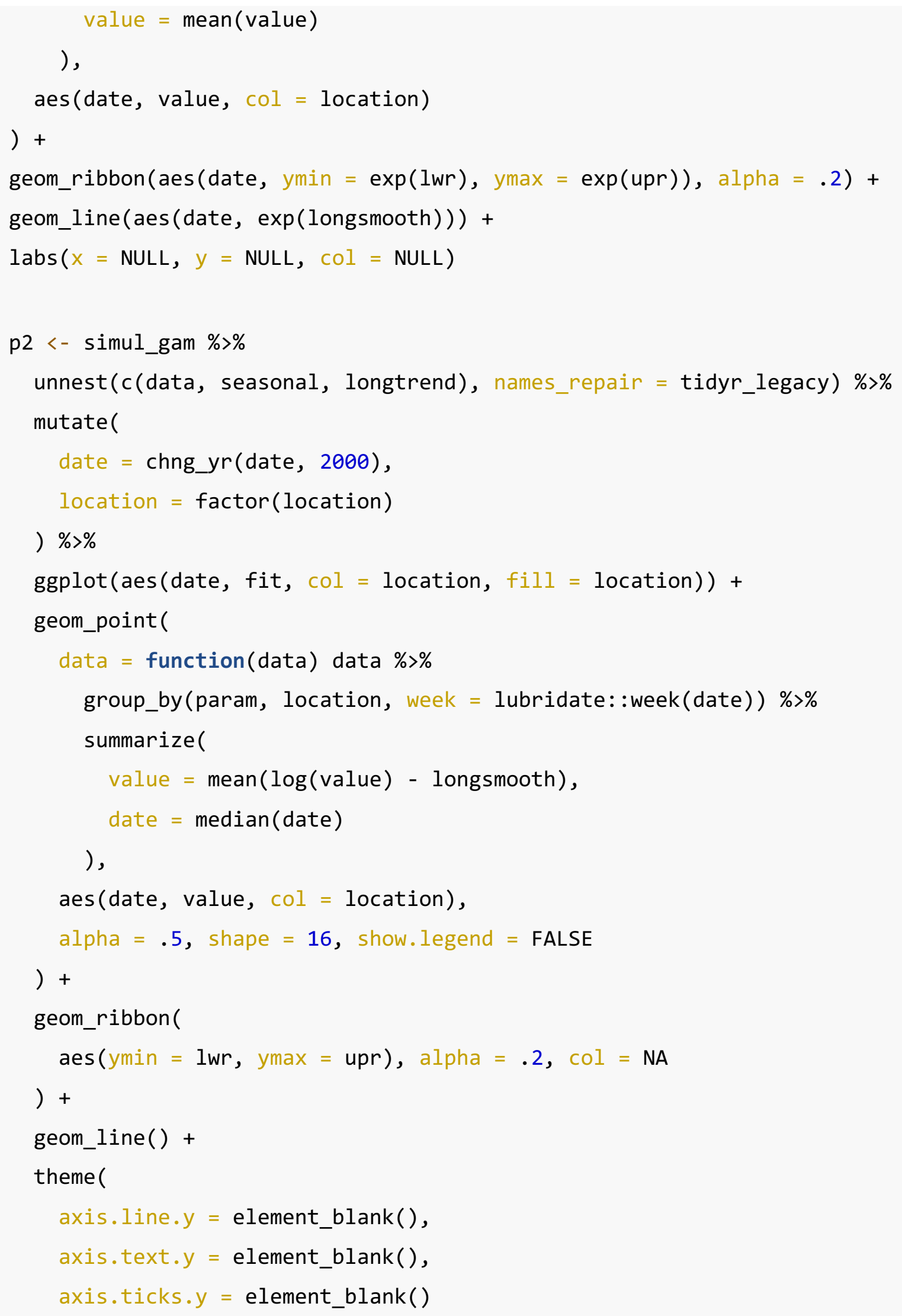


)+

scale_x_date $($ date_labels $=$ "\%b") +

$\operatorname{labs}(x=N U L L, y=N U L L, \quad C O I=N U L L)+$

guides (fill = "none")

a

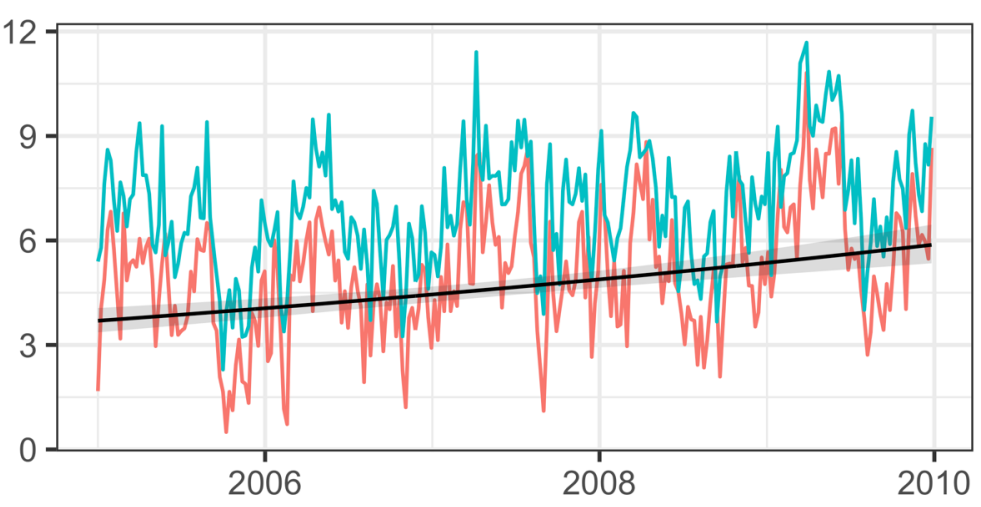

b

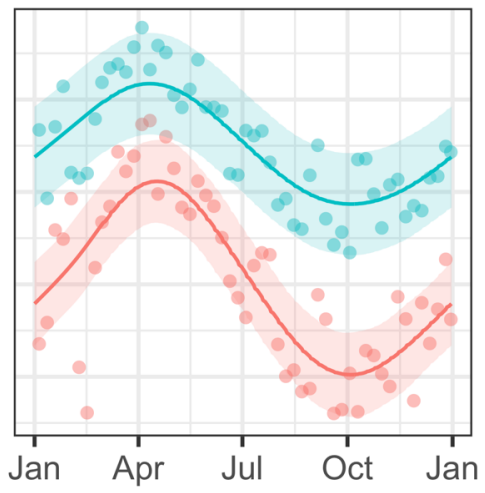

Figure S14. Plot of gam components in the fit to simulated data, described in supplementary text 4. Panel (a) shows the data and the long-term trend with a pointwise $95 \%$ confidence interval. Panel (b) shows the seasonal trend and its 95\% pointwise confidence interval along with the partial residuals aggregated into weekly means. See Figure 2 in the article body.

\section{Supplementary text 5}

library("tidyverse")

\# from doi.org/10.5281/zenodo.5139734

coupon_data <- read_csv(here: :here("zenodo/2021-06-

01_cleaned_data_coupon_study.csv"))

fit_in <- coupon_data \%>\%

filter (element == "208Pb") \%>\%

rename (po4_mg_l = initial_po4_mg_1) \%>\%

mutate_at(vars(-matches("conc_ppb")), as.factor) \%>\%

mutate( 


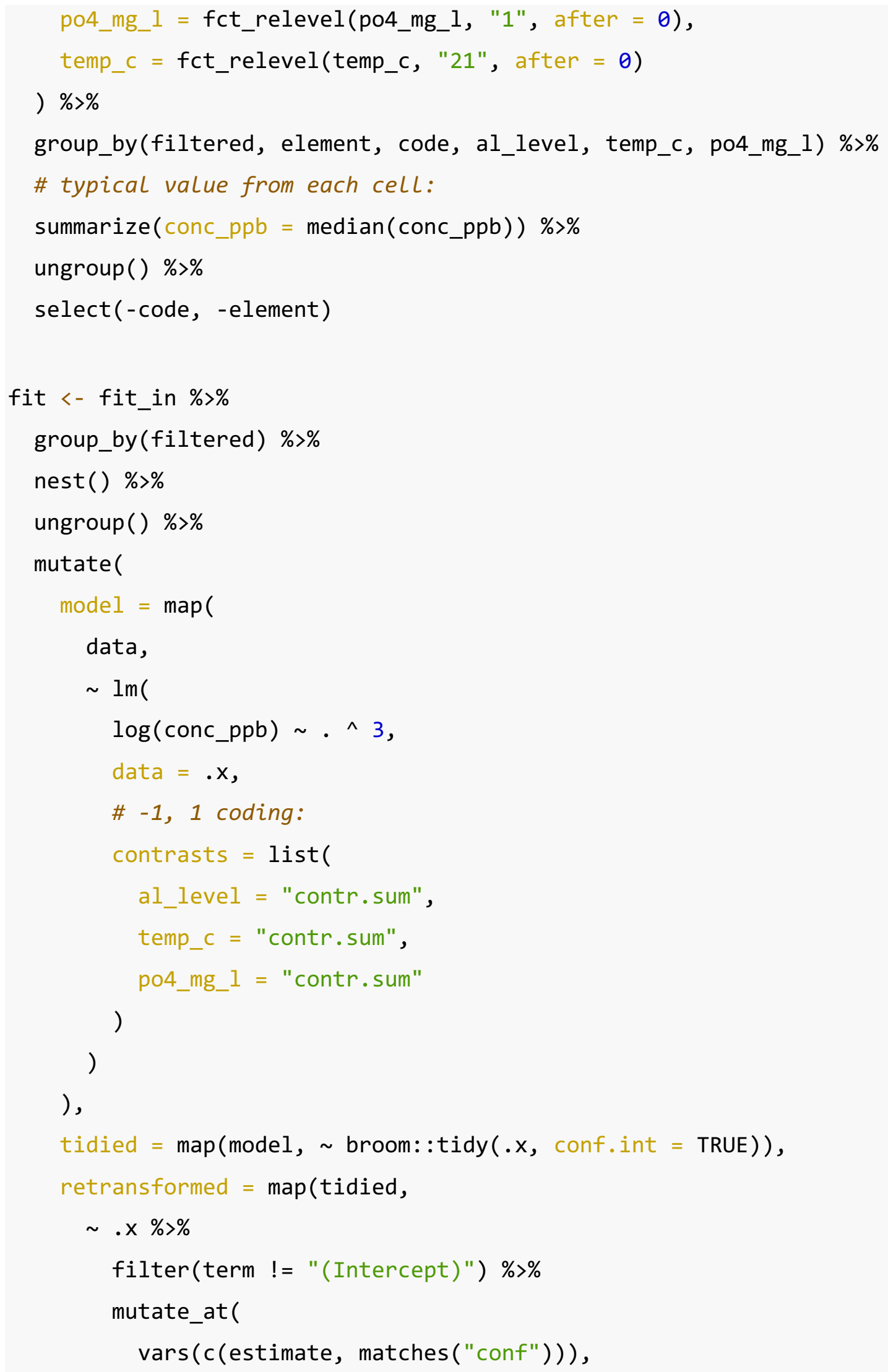




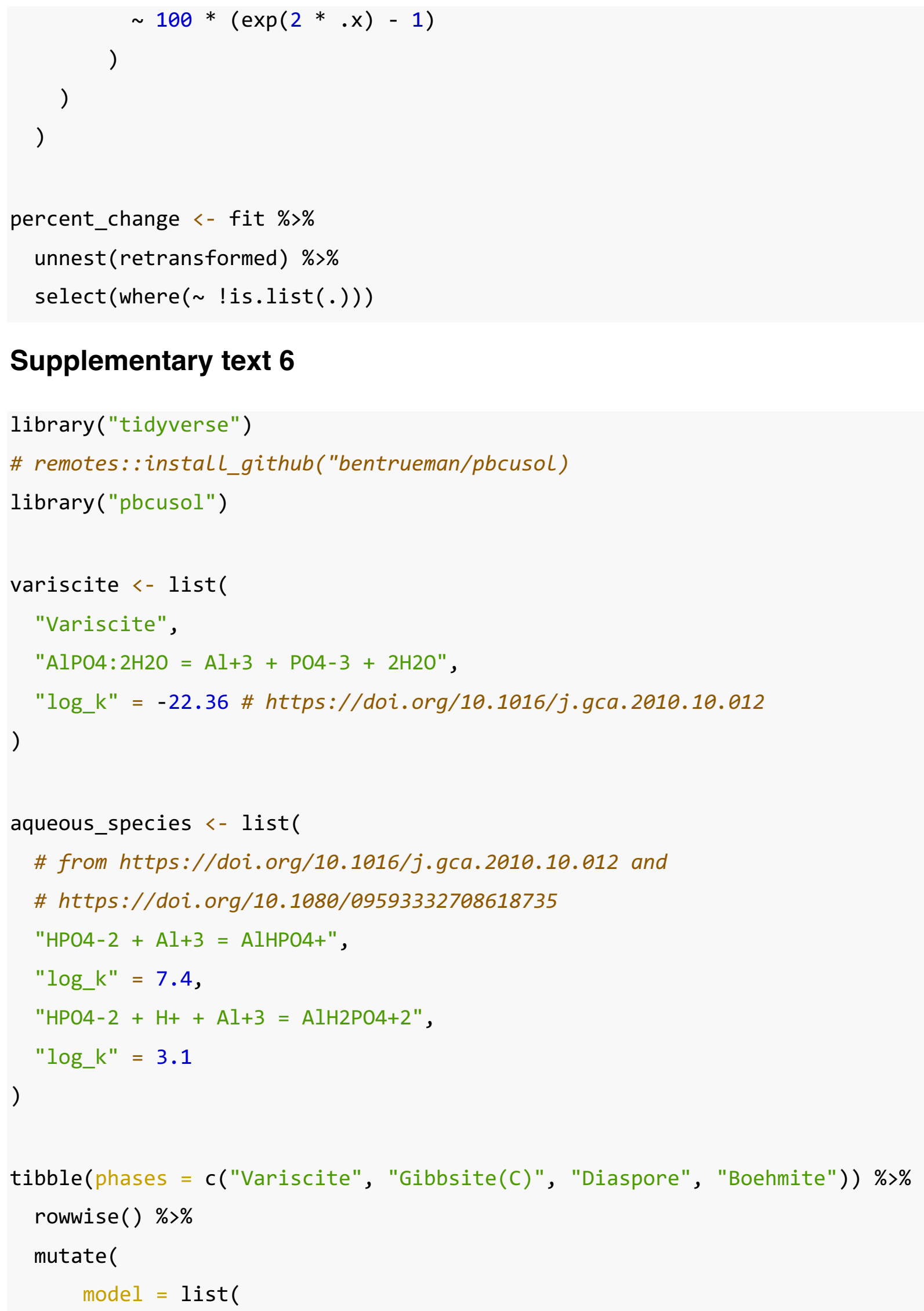




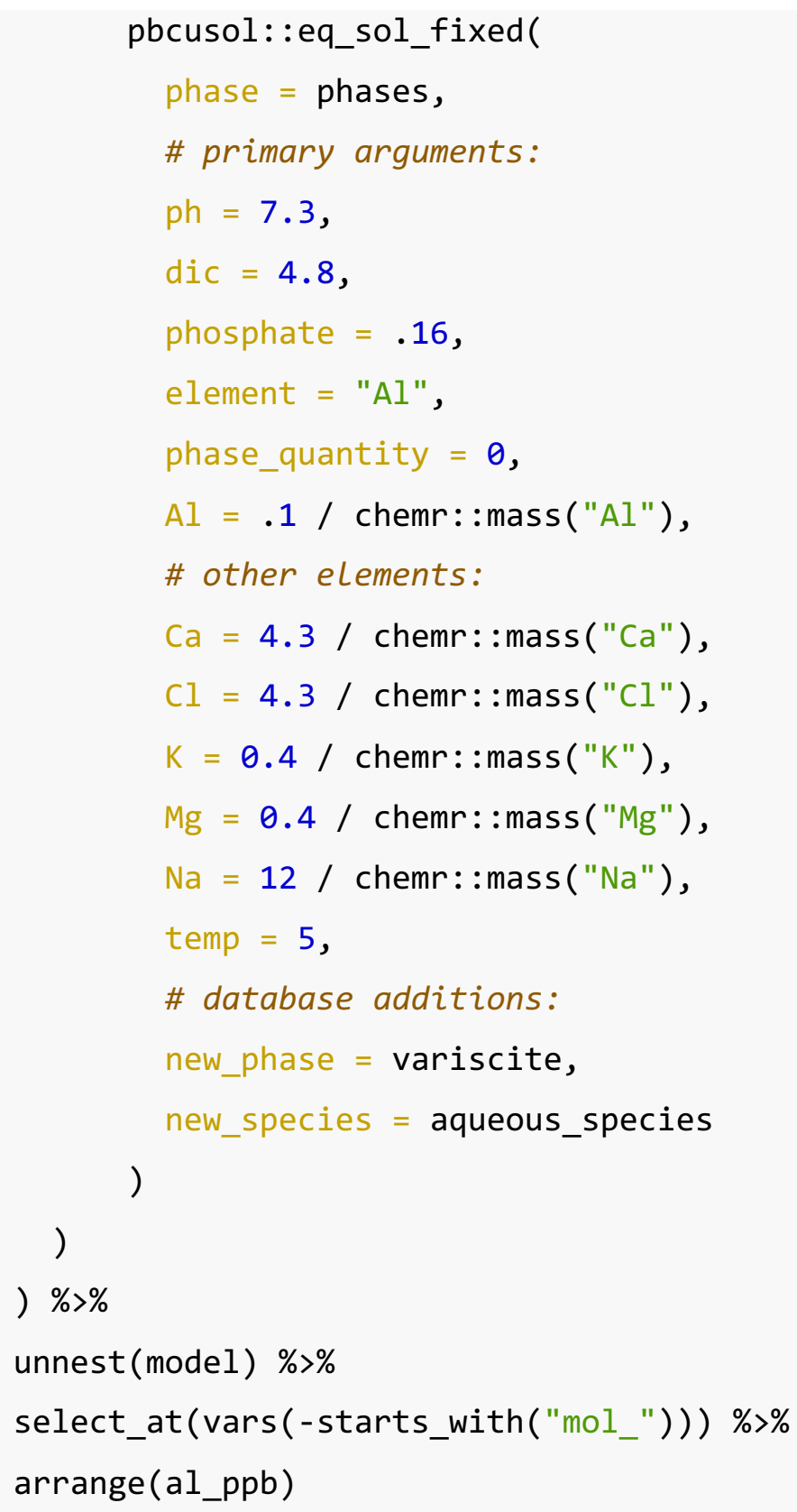

